\title{
Evaluation of a fall stocking of adult and intermediate largemouth bass (Micropterus salmoides) into two Ohio River embayments
}

Eric C. Janney

West Virginia University

Follow this and additional works at: https://researchrepository.wvu.edu/etd

\section{Recommended Citation}

Janney, Eric C., "Evaluation of a fall stocking of adult and intermediate largemouth bass (Micropterus salmoides) into two Ohio River embayments" (2001). Graduate Theses, Dissertations, and Problem Reports. 1254.

https://researchrepository.wvu.edu/etd/1254

This Thesis is protected by copyright and/or related rights. It has been brought to you by the The Research Repository @ WVU with permission from the rights-holder(s). You are free to use this Thesis in any way that is permitted by the copyright and related rights legislation that applies to your use. For other uses you must obtain permission from the rights-holder(s) directly, unless additional rights are indicated by a Creative Commons license in the record and/ or on the work itself. This Thesis has been accepted for inclusion in WVU Graduate Theses, Dissertations, and Problem Reports collection by an authorized administrator of The Research Repository @ WVU. For more information, please contact researchrepository@mail.wvu.edu. 
EVALUATION OF A FALL STOCKING OF ADULT AND

INTERMEDIATE LARGEMOUTH BASS (Micropterus salmoides)

INTO TWO OHIO RIVER EMBAYMENTS

\title{
$\underline{\text { Masters Thesis }}$
}

\author{
By \\ Eric C. Janney \\ Submitted to the Graduate Faculty of the \\ College of Agriculture, Forestry and Consumer Sciences at West Virginia University \\ in Partial Fulfillment of the Requirements \\ of the Degree \\ Master of Science \\ in \\ Wildlife and Fisheries Resources \\ Kyle J. Hartman, Ph.D., Chair \\ Patricia Mazik, Ph.D. \\ J. Todd Petty, Ph.D. \\ Scott Morrison \\ West Virginia University \\ Morgantown, West Virginia \\ 2001
}

Key Words: Largemouth bass, Stocking, Ohio River,

Copyright 2001 Eric C. Janney 


\title{
Abstract \\ Evaluation of a Fall Stocking of Intermediate and Adult Largemouth Bass \\ (Micropterus Salmoides) Into Two Ohio River Embayments
}

\author{
Eric C. Janney
}

On October 20, 1998 the West Virginia Division of Natural Resources stocked adult and intermediate size hatchery reared largemouth bass (Micropterus Salmoides) into two Ohio River embayments in an attempt to supplement existing populations. Prior to stocking each fish was fitted with an anchor tag and a visible implant elastomer mark to help ensure recognition as a hatchery-origin fish. The objective of this study was to evaluate the effectiveness of this stocking event for enhancing largemouth bass populations and improving angling opportunities in Ohio River embayment areas. A multifaceted sampling approach was incorporated to: (1) evaluate the persistence and return of stocked bass to anglers' creel relative to that of wild largemouth bass, (2) estimate fidelity of stocked largemouth bass to embayment release sites, and (3) compare return rates and cost effectiveness of the two size classes used for stocking.

Although stocked bass comprised the majority (81\%) of bass captured in electrofishing surveys conducted during the first 30 days after stocking, the percent composition declined to $50 \%$ in January 1999, and continued to decline at an exponential rate throughout 1999. Relative survival of the adult size class was estimated to be 2.9 times higher than that of the intermediate class based upon returns to electrofishing gear. A total of 203 angler interviews corresponding to 1,085 hours of angling effort were recorded during creel surveys conducted at public access landings during which only two tagged largemouth bass were reported. Tagged fish only contributed slightly to the tournament catch during the 2000 tournament season. Anglers weighed in 7 (1.4\% of total LMB catch) tagged largemouth bass during attended tournaments. This corresponds to one tagged largemouth bass captured for every 876 hours of tournament angling effort. Low return rates of stocked bass in electrofishing and angler surveys indicate that stocked fish did not make a substantial contribution to the fishery after fall, 1998. These data suggest that fall stocking of largemouth bass into Ohio River embayments in this manner only provided limited, short-term benefit to the Ohio River largemouth bass fishery. Rapid loss of stocked fish in embayment areas was most likely due to post-handling and natural mortality over the winter of 1999 combined with emigration of stocked fish out of the stocked areas into the Ohio River main-stem. 


\section{Acknowledgements}

I would like to extend thanks to the members of my graduate committee, Dr. Kyle Hartman, Scott Morrison, Dr. J. Todd Petty, and Dr. Patricia Mazik for their guidance and support throughout the course of this study. A special thanks goes out to Jason Freund and Elizabeth Hoffman for their many hours a field assisting with data collection. I would also like to express gratitude to Gary Batton for his help in overcoming the many mechanical and logistical obstacles encountered over the course of this study. Frank Jernejcic, Bret Preston, Bert Pierce, and Chris O'Bara of the West Virginia Division of Natural Resources deserve thanks for their input and suggestions. Dr. William Thayne provided advice concerning data analysis. This study was supported with funds provided by the West Virginia Division of Natural Resources. I dedicate this thesis to my parents, who provided unconditional support throughout my graduate education. 


\section{Table of Contents}

Chapter 1: Background Information and Literature Review of Largmouth Bass Biology, and the use of Cultured Fish in Fisheries Management

Life History, Biology, and Management of Largemouth Bass $\quad 1$

(Micropterus salmoides) in large river systems.

$\begin{array}{ll}\text { The use of cultured fishes in fisheries management } & 7\end{array}$

$\begin{array}{ll}\text { Literature Cited } & 19\end{array}$

Chapter 2: Evaluation of Tag Retention and Delayed Post-Stocking Mortality in Adult and Intermediate Hatchery Reared Largemouth Bass

$\begin{array}{lr}\text { Abstract } & 29\end{array}$

$\begin{array}{ll}\text { Introduction } & 30\end{array}$

Materials and Methods 33

$\begin{array}{ll}\text { Results } & 36\end{array}$

$\begin{array}{ll}\text { Discussion } & 38\end{array}$

$\begin{array}{ll}\text { Literature Cited } & 42\end{array}$

Table 1. Post handling mortality 46

Table 2. Tag retention and mark detection $\quad 47$

Table 3. Retention estimates from recapture data 48

Figure 1. Visible implant elastomer mark 49 
Chapter 3: Evaluation of a Fall Stocking of Intermediate and Adult Largemouth Bass (Micropterus Salmoides) Into Two Ohio River Embayments

$\begin{array}{ll}\text { Abstract } & 50\end{array}$

Introduction $\quad 51$

Materials and Methods

$\begin{array}{ll}\text { Results } & 62\end{array}$

$\begin{array}{ll}\text { Discussion } & 67\end{array}$

$\begin{array}{ll}\text { Literature Cited } & 75\end{array}$

Table 1. Descriptive statistics of stocked bass $\quad 82$

Table 2. Stocking densities $\quad 83$

Table 3. Chi Square table 84

Table 4. Relative Survival 85

Table 5. Black bass tournament summery 86

Table 6. Chi Square table $\quad 87$

$\begin{array}{lr}\text { Figure 1. Study area map } & 88\end{array}$

Figure 2. Mean length comparisons $\quad 89$

Figure 3. Percent composition of stocked fish 90

Figure 4. Electrofishing catch per unit effort 91

Figure 5. Stocked/Wild ratio 92

Figure 6. Catch per unit effort of creel 93

Figure 7. Length Frequency Histogram 94

Figure 8. Angler call-in distances 95 


\section{Chapter 1:}

\section{Background Information and Literature Review of Largemouth Bass Biology, And the Use of Cultured Fish in Fisheries Management}

\section{Life History, Biology, and Management of LargemouthBass (Micropterus salmoides)in large river systems.}

Life history and biology

Largemouth bass (Micropterus salmoides), the largest member of the sunfish family (Centrarchidea), were first described in 1802 (Jenkins and Burkhead 1994). It is one of seven species included in the genus Micropterus, and is the principle warm-water predatory fish species, as well as the most popular warm-water sport fish in North America (Heidinger 1975). The largemouth bass's native range originally included the Great Lakes, St. Lawrence, and Mississippi basins as well as the Gulf and south Atlantic slopes (MacCrimmon and Robbins 1975). However, due to extensive stocking beginning as early as the 1870 's it is now found ubiquitously throughout North America. Two subspecies of largemouth bass are recognized: $M$. s. salmoides (northern largemouth bass); and M. s. floridanus (Florida largemouth bass)(Ramsey 1975). The Florida subspecies, by far the least common and distributed of the two, was originally confined to the Florida peninsula (Jenkins and Burkhead 1994), but its range has been expanded, through stocking programs, to incorporate the southern United States and California. Largemouth bass inhabit ponds, lakes, reservoirs, streams, marshes, and rivers, and prefer warm water temperatures. Although largemouth bass can be found in open water, littoral areas containing aquatic macrophytes or large woody debris are preferred. Killgore et al. (1989) found 
that largemouth bass in the Potomac River were most abundant in areas with intermediate and high macrophyte densities. Although largemouth bass are mostly associated with lentic waters (Trautman 1981), they are also relatively common in lotic systems where they inhabit low gradient pools, oxbows, and backwater habitats (Jenkins and Burkhead 1994). The construction of high lift dams and subsequent impoundment of large rivers throughout the United States has greatly increased low flow habitat types favored by largemouth bass. This habitat shift may have led to an increase in largemouth bass populations in large river systems throughout the United States (Trautman 1981; Sheehan and Rasmussen 1999). Although largemouth bass are typically thought of as a lentic species, Marler and Jackson (1992) found that relative abundance in tailwater habitats of the Tennessee-Tombigbee waterway equaled or exceeded those in more lentic bendway habitat areas. Navigation channels were found to contain the lowest relative abundance (Marler and Jackson 1992).

Water quality requirements of largemouth bass have been intensively studied and are well defined. Optimum growth for largemouth bass has been shown to occur at around $27^{0} \mathrm{C}$ (Coutant 1975). Dissolved oxygen requirements vary, but at least $6.0 \mathrm{ppm}$ is usually required for optimum growth and mortality is likely to occur at prolonged exposure to levels $<1.0 \mathrm{ppm}$ (Bulkley 1975). Largemouth bass can tolerate salinity levels of up to 11.8 ppt where they occur in estuarine habitat along the Atlantic and Gulf coast (Bulkley 1975).

Largemouth bass spawning takes place in the spring when water temperatures range between $15^{\circ}$ and $20^{\circ} \mathrm{C}$ (Kramer and Smith 1960). Like other members of the Centrarchidae family, male largemouth bass construct spawning nests in 1 to 4 feet of water (Heidinger 1975), and guard the nest against predators until the swim-up of larvae occurs. Largemouth bass inhabiting tidal areas of the Hudson River were found to avoid spawning along shoreline areas 
exposed to wave action (Nack et al 1993). Spawning activity was concentrated in the mouths of creeks, coves, and backwater habitats where wave and tidal action were minimal (Nack et al. 1993). The inundated shorelines of backwater and embayment areas have also been shown to provide vital largemouth bass spawning and nursery habitats in large river systems (Pitlo 1992; Raibley et al. 1997).

Sexual maturity of largemouth bass is dependent more upon size than on the age of the fish. Larger bass tend to spawn earlier in the season than those that have just reached sexual maturity (Heidinger 1975). Females reach spawning size somewhere around $250 \mathrm{~mm}$ and males at a somewhat smaller size (Heidinger 1975). Largemouth bass in the southern parts of the range may reach sexual maturity during their second year due to extended growing seasons, while bass found in the northern part of the range may require 3 to 4 years to reach sexual maturity. Research has shown that early cohorts exhibit higher survival rates than cohorts spawned later in the season (Pine et al. 2000).

Largemouth bass exhibit an ontogenetic niche shift in forage utilization. Juveniles start out feeding on zooplankton, but switch to a diet consisting of small insects, crustaceans, and larval fish after they reach a size of between 50 and $100 \mathrm{~mm}$ (Goldstein 1993). The timing of this shift to higher energy food sources can play an important role in determining survival and mortality rates of largemouth bass cohorts (Olson 1996). Largemouth bass are primarily piscivorous at the adult life stage (Heidinger 1975; Storck 1986; Hedrick 1995), but are opportunistic predators and will prey on a wide array of aquatic and terrestrial organisms that are between 30 to 50 percent of their total body length (Goldstein 1993). Where they co-occur, gizzard shad (Dorosoma cepedianum) are a primary and important food source for largemouth bass (Storck 1986; Hedrick 1995). Hedrick (1995) found that largemouth bass diets in the Ohio 
River consisted primarily of gizzard shad in the fall, but switched to crayfish and small forage fish (Lepomis spp.) during spring and summer months.

Movement and home-range characteristics of largemouth bass are well studied, but results of these studies are disparate. Lewis and Flickinger (1967) reported that largemouth bass had a tendency to remain in the same section of shoreline (within $30 \mathrm{~m}$ ). Copeland and Noble (1994) reported similar findings with young-of-year (YOY) largemouth bass. Largemouth bass populations inhabiting large river and impoundment systems have been shown to exhibit a wide range of seasonal movements (Pitlo 1992; Raibley et al. 1997). Large river largemouth bass populations have also been shown to seek thermal and flow refuge as well as spawning habitat in backwater and embayment areas (Pitlo 1992; Raibley et al. 1997). Forage abundance has also been shown to influence home-range size of largemouth bass, with forage density negatively influencing home range size (Savitz et al. 1983).

Although population dynamics of largemouth bass in small ponds and reservoirs have been studied in great detail, little information exists concerning the population dynamics of largemouth bass inhabiting temperate large river systems. Evidence exists to suggest that extreme variations occur in young-of-year (YOY) largemouth bass populations (Summerfelt 1975) in these systems. This extreme year to year variation has been suggested to be independent of the number of spawning fish the previous spring, and is thought to be due to environmental conditions such at water temperature, and wave action during the first weeks of life (Summerfelt 1975). Raibley et al. (1997) suggested that strong largemouth bass cohorts in the Illinois River were correlated with flooding events in the spring. They hypothesized that the positive correlation observed between spring floods and year class strength resulted from more suitable spawning/rearing habitat being provided by inundated shoreline. 


\section{Largemouth bass management}

The management of largemouth bass populations has received much attention since the inception of fisheries management in North America, and research on the impacts of the various management techniques is vast. Largemouth bass management is a source of considerable debate among fisheries professionals and fisherman alike. Agencies use a variety of tools to reduce mortality and directly enhance bass populations. State agencies can directly reduce mortality of largemouth bass through the use of various harvest regulations such as creel limits, size restrictions, and season closures, which have all been used to lower mortality and impacts caused by angling. In a survey, Fox (1975) found that every state with the exception of Wyoming has some sort of statewide daily creel limit on black bass species.

Season closure has traditionally been a method of reducing impacts of fishing during the spawning season. Impacts of angling during the spawning season to largemouth bass populations are debated among fisheries scientists. Although studies have shown that nest mortality can be greatly elevated if adult black bass are removed from the nest (Kieffer et al. 1995; Cook et al. 2000), it has not been shown to what affect angling during the spawning season has at the population level. Managers have also used length and slot limits to reduce harvest of large and intermediate size bass. Ming and McDannold (1975) reported that a 12-in length limit on largemouth bass was successful in allowing population recovery and in reducing an overpopulation of bluegill (Lepomis macrochirus).

Fisheries professionals also use indirect management techniques to enhance largemouth bass populations and improve angling opportunities. Habitat improvements and manipulation of hydrological processes in rivers and reservoirs are commonly used to manage for largemouth bass populations (Keith 1975; Gent 1995). Water level management has been shown to play an 
important role in increasing bass production in reservoirs and rivers (Keith 1975; Sammons et al. 1999). High water levels during the spring spawning season can benefit largemouth bass by providing spawning and nursery habitat as well as increasing food sources from terrestrial inputs. Most large rivers in the United States have been impounded and channelized to facilitate commercial navigation. The addition of high-lift dams in large river systems throughout the United States has increased the availability of lentic habitat in most large river systems. This shift in habitat type initially provided more suitable habitat for lentic species such as centrarchids by creating flooded backwaters and other types of favorable habitat. Although the addition of dams may have initially provided favorable habitat for lentic species such as largemouth bass, increased sedimentation due to impoundment is causing the loss of these habitat types over time in some systems (Sheehan and Rasmussen 1999). Habitat improvements in large river systems can be beneficial to largemouth bass populations. Backwater habitat areas of most large river systems are subject to continuous sedimentation (Gent et al. 1995). These backwater areas have been shown to be important to largemouth bass and other fish by providing spawning and nursery habitat (Sheaffer and Nickum 1986; Nack et al. 1993; Copp 1997), as well as refuge during high winter flows (Pitlo 1992; Raibley et al. 1997). Rehabilitation of a backwater area of the upper Mississippi River through the construction of a deflection levee was shown to have positive effects on water quality and catch rates of largemouth bass (Gent et al. 1995). 


\section{The use of cultured fishes in fisheries management}

\section{Introduction}

Artificial propagation has been linked to the enhancement of fish populations since the beginning of fisheries management in North America (White et al. 1995). Fisheries managers have used cultured fish as a method of enhancing existing fish populations and establishing transplanted populations in North America since the 1800's. Fish stocking is currently conducted in every state and in almost all of the various aquatic ecosystem types found in North America (Horak 1995).

Supplemental and maintenance stocking are the two major types of stocking programs carried out by management agencies to enhance fish populations (Heidinger 1999). Supplemental stocking is a method of enhancing an existing fish population in instances where recruitment and mortality are limiting factors (Heidinger 1999). Extensive supplemental stocking programs are carried out annually in most states, but very little evaluation is performed to monitor the survival, movements, growth analysis, and percent of stocked fish caught by anglers (Murphy and Kelso 1986).

Maintenance stocking is another type of population enhancement method used by fisheries managers to create new angling opportunities. This type of stocking program is mainly used in areas where recruitment or natural reproduction does not occur (Heidinger 1999). Maintenance stocking can be divided into put-and-take (PT) and put-grow-and-take programs (PGT). Put-and-take stocking programs rely on stocking harvestable size fish (Heidinger 1999). These programs are usually designed to create an immediate fishery in systems that incur heavy angling pressure, but cannot sustain viable populations due to poor water quality, paucity of habitat, or lack of an adequate food supply (Hartman and Preston 2001). Put-and-take programs rely on a regular stocking schedule to maintain angling opportunities (Stone 1995). In waters 
where seasonally high water temperatures, lack of habitat, or poor water quality prevent fish from carrying over from year to year, catchable size fish can be stocked during high use periods to provide immediate angling opportunities. Some management agencies do not consider fish populations maintained by PT stocking to be a natural resource, but instead as a means of providing recreational opportunity (Stone 1995).

Put-grow-and-take stocking programs are generally designed for systems where fish populations survive and grow from year to year, but reproduction and/or recruitment are limiting factors. Waters that have sufficient water quality and habitat to carry-over fish from year to year but do not support natural reproduction are usually stocked with fingerling-sized fish. State management agencies use PGT stocking programs to produce angling opportunities in artificially created impoundments and streams that would otherwise not support these types of fisheries (Kinman 1995).

Although the use of cultured fish can be a valuable tool to managers for enhancing fish populations, reintroducing endangered species, and creating angler opportunities, there are undesirable biological, economic, and social impacts associated with fish stocking that managers must consider (Marnell 1986). Many unanswered questions remain concerning the destructive effects of stocked fish on intraspecific and interspecific wild fish populations as well as aquatic ecosystems in general. These deleterious effects can range from genetic and disease risks, to competition and predation. The likelihood of disease outbreaks can increase if fish populations are enhanced to unnaturally high levels, or new parasitic organisms are introduced into a system by means of cultured fish (Goede 1986). Undesirable genetic effects caused by stocking cultured fish include (1) loss of genetic variation; (2) introgression of exogenous genes; (3) artificial selection; and (4) domestication selection (Campton 1995). Loss of genetic variation can be 
attributed to small breeding populations associated with hatchery production (Campton 1995). Introgression of exogenous genes can occur if genes are imported into a system through brood fish that are captured from one system and used at a hatchery facility located in a different system (Campton 1995). Artificial selection occurs when hatchery personnel select for various traits when selecting brood fish. These traits can include size, run or spawn timing, or spawning location. Domestication selection can take place when fish naturally evolve for increased fitness in hatchery conditions although this may decrease fitness in natural environments. An overall decrease in the viability of wild fish populations can result from these deleterious genetic effects when hatchery stocks interbreed with natural populations (Flag et al. 1995; White et al. 1995). Improving hatchery management practices can help to reduce the undesirable genetic effects listed above (Campton 1995). Hatchery managers should attempt to randomly select brood fish to limit human bias, which can lead to artificial selection. Increasing the number of fish used for propagation can help reduce the loss of genetic variation of wild populations (Campton 1995). Selecting brood fish from the same systems that are stocked can help hatchery managers eschew the introgression of exogenous genes. Stocking fish during early life stages can help to ameliorate genetic drift problems associated with fish culture techniques (Hartman and Preston 2001). Using earlier life stages allows a larger number of adult fish to be used for producing offspring due to the fact that more space and water volume are available for keeping adult fish for brood purposes.

Stocking programs can also have negative influence on the public's attitude and expectations. The use of cultured fish to compensate for declining fish populations due to habitat degradation, poor water quality, or other anthropogenic alterations can instill a false sense of security in society (White et al. 1995). Furthermore, angler expectations and perceptions can 
force the continuance of a stocking program even though it has been found to be unsuccessful or ineffective at meeting its objectives (White et al. 1995).

Stocking exotic and transplanted species for the purpose of increasing fishing opportunities.

Fisheries managers are under constant pressure from their public constituencies to improve fishing opportunities. Introducing exotic or transplanted sport fish has been one method that agencies have employed to provide constituents with new angling opportunities. Currently, 42 species of exotic fishes have become established in North America (Ross 1991). Although many of these exotic species were introduced accidentally, natural resource management agencies are responsible for a large number of the non-native introductions in North America (Horak 1995). Many exotics have been introduced through deliberate stocking for the purpose of improving angling opportunities.

The introduction of exotic sport fish via stocking has been especially common in arid western states where native fish diversity and hence angling opportunities have been traditionally low (Horak 1995). In California, 30 different fish species were introduced by the California Fish Commission prior to 1900 (Lee 1995). Ninety-nine percent of angling effort in Colorado and Arizona is for nonnative sport fishes (Horak 1995).

Although stocking introduced fishes can improve angling opportunities, it can also have undesirable effects on native fish communities and aquatic ecosystems. Introduced species may affect native communities in a variety of ways. Some of the negative effects that introduced species can inflict upon native fish communities are: (1) alter the habitat of the system to which they are introduced, (2) introduce disease or parasites, (3) hybridize with native species which results in a loss of genetic diversity, or (4) cause trophic or spatial alterations (Ross 1991). 
Exotic sport fish are listed as a cause in the population decline of $73 \%$ fishes listed as Threatened or Endangered under the Endangered Species Act (Lassuy 1993).

Brook trout (Salvelinus fontinalis), a native to eastern cold-water streams, have been transplanted, via stocking, to rocky mountain streams where hybridization with native bull trout (S. confluentus) is common and extensive (Leary et al.). This is an example of a transplanted fish that has hybridized with a native species resulting in a loss of genetic integrity to the native fish population. Brook trout have also played a role in the decline of cutthroat trout populations (Oncorhynchus clarki) throughout the west (Fausch 1989). Brook trout are able to outcompete native cutthroat trout in all but the highest gradient portions of the streams inhabited by cutthroats (Fausch 1989).

So, if it has been shown that stocking exotic and transplanted fishes can potentially have disastrous effects on native fish assemblages, why do natural resource management agencies continue to stock them? Political pressure, financial benefit, and angler expectations are all obvious reasons why management agencies continue to stock transplanted and exotic species. Recreational fisheries in states such as Colorado and Arizona, as well as other western states depend almost entirely on nonnative fishes (Horak 1995). If these stocking programs were abolished, there would be tremendous losses in angling opportunity, which would in turn result in reductions of license sales and revenue generated by anglers.

Does this mean that all nonnative stocking programs are detrimental and should be discontinued? Although stocking nonnative fishes can prove to be disastrous, in many situations it can provide tremendous angling opportunities while inflicting negligible consequences to the native biota. One example of a stocking program that has provided a beneficial fishery with little negative effect is the establishment of pacific salmon in Lake Ontario. Coho (Oncorhynchus 
kisutch) and Chinook (O. tshawytscha) salmon were introduced into Lake Ontario in the late 1960's to control introduced populations of rainbow smelt (Osmerus mordax) and alewife (Alosa pseudoharengus) while providing fishing opportunities in a system with little human value as a fishery (Lange et al. 1995). Lange et al. (1995) reported the economic benefits created by the Lake Ontario fishery to be $\$ 69$ million above the costs associated with stocking. In addition, the stocked salmon have helped control smelt and alewife populations that are considered to be an exotic nuisance.

The use of cultured fish to restore or reintroduce threatened and endangered populations.

Habitat degradation, poor water quality, and exotic species have led to the decline of native fish populations in North America (Rahel et al. 1999). As conservation values have evolved to incorporate the inherent value of biological integrity, more emphasis is being placed upon restoring populations of non-game as well as sport-fish. State and Federal agencies are legally required to prevent the loss of native species (Rahel et al. 1999).

Fisheries managers commonly use cultured fish to restore decimated fish populations. Hatchery-cultured fish are called for in the restoration plans of several fish species listed under the Endangered Species Act. Hatchery-reared Atlantic sturgeon (Acipenser oxyrinchus) are being used to accelerate the restoration process of existing populations and to reintroduce populations into drainages where they have been extirpated (Waldman 1998). Cultured fish are important to the restoration of Atlantic sturgeon due to the slow growth rates and low reproductive characteristics of the species. Without the aid of hatchery-cultured fish, recovery attempts would not likely see significant population increases for many years (Waldman 1998). 
The Wyoming Department of Game and Fish calls for the use of cultured Colorado River cutthroat trout (O. clarki pleuriticus) as part of a management plan aimed at expanding its current range, which has been reduced to $1 \%$ of its original area (Stone 1995). Another objective of this stocking program is to improve the genetic integrity of existing populations. Hybridization with transplanted rainbow trout (O. mykiss) has led to genetic degradation in remaining Colorado River cutthroat tout populations (Stone 1995). Therefore, hatchery reared fish are being used to increase the genetic purity of extant cutthroat trout stocks (Stone 1995).

One problem fisheries managers face when trying to reintroduce a species into an area in which it has been extirpated is the fact that in many cases individual, stock-specific gene pools are not available (Radonski \& Loftus 1995). Radonski and Loftus (1995) point out the difficulties that managers have faced in the restoration of Atlantic salmon (Salmo salar) due to the loss of stock-specific gene pools. Managers have been forced to work with a limited nonnative gene pool while trying to restore Atlantic salmon populations throughout their original range (Radonski \& Loftus 1995).

\section{Overview of largemouth bass stocking}

Largemouth bass are the most commonly stocked warm-water fish species and are currently stocked in 41 states (Buynak et al. 1999). Management agencies in the U.S. and Canada, annually stock around 21 million largemouth bass (mostly fry and fingerlings) (Heidinger 1999). Black bass stocking programs are carried out to supplement existing populations, introduce bass into new or reclaimed waters, correct prey/predator imbalances, or to satisfy anglers (Smith and Reeves 1986). Although millions of dollars are spent annually stocking largemouth bass, studies evaluating effectiveness and biological impacts of these 
management programs are most often inadequate or nonexistent. The few evaluations of largemouth bass stocking programs that have been published indicate that return rates are usually low and results are mixed (Loska 1982; Boxrucker 1986; Ryan et al. 1996; Buynack et al. 1999; Buynack and Mitchell 1999).

Factors affecting the survival of stocked fish can include; fish size, stocking season, ecological interactions with resident fish, disease, stocking rate, stocking technique, as well as a multitude of other biotic and abiotic factors (Murphy and Kelso 1986). Boxrucker (1980) attributed poor returns of largemouth bass fingerlings stocked into small Oklahoma impoundments to high age $1+$ natural mortality. Although most largemouth bass are stocked as fingerlings or juveniles, several studies have shown that stocking adult fish increases survival and return rates (Loska 1982). Traditionally, the high costs associated with raising adult largemouth bass have limited their use in stocking programs (Snow 1968), but improvements in rearing techniques and the development of artificial feeds have increased the practicality of stocking advanced size fish (Satterfield and Flickinger 1986). Several studies have evaluated stocking programs that used intermediate size largemouth bass and found that although natural mortality rates of bass stocked at advanced sizes are lower than those of fingerlings, they can be extremely vulnerable to harvest and catch-and-release mortality (Lawson and Davies 1977; Buynak et al. 1999).

Stocking rates have been shown to play an important role in optimizing cost-efficiency of largemouth bass stocking programs (Buynak and Mitchell 1999). Augmenting natural populations through supplemental stocking can increase natural mortality rates by causing a shift from density-independent to density-dependent control factors, thus undermining enhancement efforts (Snow 1978). Terre et al. (1993) found that supplemental stocking success was inversely 
related to recruitment levels of the wild bass populations, suggesting that competition for limited resources may exist between stocked and wild largemouth bass.

Genetic makeup and rearing method of stocked fish have also been shown to influence post-stocking survival (Reisenbichler and McIntyre 1977; Larscheid et al. 1999). Nonnative largemouth bass stocks of the same subspecies have been shown to exhibit poorer fitness and performance traits relative to native stocks that have evolved to specific local environments (Philipp and Claussen 1995). Studies have also indicated that largemouth bass as well as other predatory species raised on an artificial pellet diet exhibit much higher post-stocking mortality than fish raised on a minnow diet (Larscheid et al. 1999; Personal communication, Wes Porak, Florida Fish and Wildlife Conservation Commission).

Guidelines, criteria and, evaluation of stocking programs

The use of maintenance and enhancement stocking programs play a significant role in the management of North American fisheries. State management agencies allocate large portions of their annual budgets on fish culture and stocking programs. For example, Oregon spent $42 \%$ of its 1993-1995 biennial budget on fish propagation while only appropriating 3\% to manage for natural production (White et al. 1995). Stocking programs accounted for $42 \%$ of the funds allocated by the "Federal Aid in Sport Fish Restoration Program" for salmonid management from 1991 to 1995 (McGurrin et al. 1995). In order to maximize benefits to anglers while minimizing risks to wild fish stocks and aquatic ecosystems, the guidelines and criteria set forth by the American Fisheries Society (1995 Position Statement) dictating when, where, what, and how to use cultured fish need to be followed. This can be accomplished through the use of rigorous biological, social, and economic evaluation. 
Prior to the inception of any management plan containing the use of cultured fish, the biological feasibility of such a plan should be evaluated. This evaluation should include: (1) determining the status and trends of fish populations and environmental conditions to determine if stocking is necessary, (2) determine the carrying capacity of the system to conclude appropriate stocking rates, (3) evaluate habitat restoration opportunities to restore biological integrity to the system and minimize the need for stocking, (4) conduct a pilot study or review relevant literature to evaluate the survival, growth, recruitment, and reproduction of stocked fish, (5) conduct a pilot study in a controlled setting to evaluate beneficial and harmful effects of stocking, and to develop stocking protocols (American Fisheries Society 1995).

The assessment of a stocking program's success can be evaluated through the use of a variety of biological, economic, and social parameters. Survival of stocked fish is the most common and basic post-stocking evaluation method (Murphy and Kelso 1986). Mark and recapture methodology can be used to provide a direct estimate of mortality (Buynak et al. 1999; Buynak and Mitchell 1999), or mortality can be evaluated indirectly be measuring return to creel of stocked fish (Murphy and Kelso 1986). Growth analysis, reproduction, genetic composition, and movement are also valuable biological parameters for evaluating a stocking program's success (Murphy and Kelso 1986). The social benefits provided by stocking are one of the most important factors to consider when evaluating the success of a stocking program (Murphy and Kelso 1986). Managers must determine whether the benefits provided to society from stocking outweigh the cost. Measuring the cost associated with a management program is relatively easy, but the social benefits provided by such programs can be extremely difficult to quantify. 


\section{The future role of cultured fish in fisheries management}

Originally, managers saw cultured fishes as a solution for replenishing fish stocks depleted from years of over fishing, habitat loss, and declining water quality (White et al. 1995). Also, fisheries managers stocked transplanted sport fish into waters outside their native range to increase angling opportunities for the public (Horak 1995). Currently, an estimated 2.5 billion sport fish are stocked in North America every year (Heidinger 1999).

Societies' land ethic has evolved this century from an anthropocentric view of natural resource use, to a view in which natural resources have inherent value. As views have changed, the objectives of fisheries management also have changed. Modern fisheries management has been defined as "the protection, maintenance, and rehabilitation of native biota, their habitats, and life-support systems to ensure ecosystem sustainability" (Olver et al. 1995). In today's society, fishery biologists must strike a balance between protecting the biological integrity of the resources they manage while also providing constituents with quality angling opportunities. Views on the use of hatchery fish have changed tremendously as our knowledge of fish biology has increased. Once viewed as a panacea for replenishing diminishing fish stocks and increasing angling opportunities, fish stocking practices have come under increased scrutiny for the deleterious effects they can inflict upon aquatic ecosystems, as well as for the high costs associated with these programs (White et al. 1995). There have been many instances where stocking programs have been shown to have detrimental effects on native fish communities while providing little or no human value (McGurrin et al. 1995). Two thirds of fish extinctions brought about by exotic species have been the result of intentional introductions for the benefit of sportfishing (McGurrin et al. 1995). With the use of cultured fish being supported and relied upon by some management agencies yet challenged by others, the guidelines set forth by the 
American Fisheries Society (1995) concerning when the use of cultured fish is appropriate need to be adhered to. 


\section{Literature Cited}

American Fisheries Society Symposium. 1995. Pages 585-586 in R. H. Stroud, editor. Fish culture in fisheries management. American Fisheries Society, Fish Culture Section and Fisheries Management Section, Bethesda, Maryland.

Boxrucker, J. 1986. Evaluation of Supplemental Stocking of Largemouth Bass as a Management Tool in Small Impoundments. North American Journal of Fisheries Management 6:391-396.

Bulkley, R. V. 1975. Chemical and Physical Effects on the Centrarchid Basses. Pages 286-294 in H. Clepper, editor. Black bass biology and management. Sport Fishing Institute, Washington, D.C.

Buynak, G. L., and B. Mitchell. 1999. Contribution of Stocked Advanced-fingerling Largemouth Bass to the Population and Fishery at Taylorsville Lake, Kentucky. North American Journal of Fisheries Management 19:494-503.

Buynak, G. L., B. Mitchell, D. Michaelson, and K. Frey. 1999. Stocking Subadult Largemouth Bass to Meet Angler Expectations at Carr Creek Lake, Kentucky. North American Journal of Fisheries Management 19:1017-1027.

Campton, D. E. 1995. Genetic Effects of Hatchery Fish on Wild Populations of Pacific Salmon and Steelhead: What Do We Really Know? Pages 337-353 in R. H. Stroud, editor. Fish culture in fisheries management. American Fisheries Society, Fish Culture Section and Fisheries Management Section, Bethesda, Maryland. 
Cooke, S. J., D. P. Philipp, J. F. Schreer, and R. S. McKinley. 2000. Locomotory Impairment of Nesting Male Largemouth Bass Following Catch-and-Release Angling. North American Journal of Fisheries Management 20:968-977.

Copeland, J. R., and R. L. Noble. 1994. Movements by Young-of-Year and Yearling Largemouth Bass and Their Implications for Supplemental Stocking. North American Journal of Fisheries Management 14:119-124.

Copp, G. H. 1997. Importance of Marinas and Off-Channel Water Bodies as Refuges for Young Fishes in a Regulated Lowland River. Regulated Rivers: Rsearch and Management, Vol. 13, 303-307.

Countant, C. C. 1975. Responses of Bass to Natural and Artificial Temperature Regimes. Pages 272-285 in H. Clepper, editor. Black bass biology and management. Sport Fishing Institute, Washington, D.C.

Fausch, K. D. 1989. Do Gradient and Temperature Affect Distributions of, and Interactions Between, Brook Charr (Salvelinus fontinalis) and other Resident Salmonids in Streams? Physiol. Ecol. Japan, Spec. Vol. 1: 303-322.

Flag, T. A., F. W. Waknitz, D. J. Maynard, G. B. Milner, and C. V. W. Mahnken. 1995. The Effect of Hatcheries on Native Coho Salmon Populations in the Lower Columbia River. Pages 366 - 375 in Schramm and Piper, editors. Uses and Effects of Cultured Fishes in Aquatic Ecosystems. American Fisheries Society, Bethesda, Maryland.

Fox, A. C. 1975. Effects of Traditional Harvest Regulations on Bass Populations and Fishing. Pages 392-398 in H. Clepper, editor. Black bass biology and management. Sport Fishing Institute, Washington, D.C. 
Gent, R., J. Pitlo, Jr., and T. Boland. 1995. Largemouth bass response to habitat and water quality rehabilitation in a backwater of the upper Mississippi River North American Journal of Fisheries Management 15:784-793.

Goede, R. W. 1986. Management Considerations in Stocking of Diseased or Carrier Fish. Pages 349-355 in R. H. Stroud, editor. Fish culture in fisheries management. American Fisheries Society, Fish Culture Section and Fisheries Management Section, Bethesda, Maryland.

Goldstein, R. M. 1993. Size Selection of Prey by Young Largemouth Bass. Proc. Annu. Conf. Southeast. Assoc. Fish and Wildl. Agnecies 47:596-604

Hartman, K. J. and B. Preston. 2001. In: Fish Hatchery Management, 2nd edition. G. Wedemeyer, editor. American Fisheries Society, Bethesda, MD.

Hedrick, J. D. 1995. A Bioenergetics Evaluation of Growth and diet of Three Sport Fishes in the Ohio River, West Virginia. Masters Thesis. West Virginia University, Morgantown, West Virginia.

Heidinger, R. C. 1999. Stocking for Sport Fisheries Enhancement. Pages 375-398 in Kohler, editor. Inland Fisheries Management in North America, $2^{\text {nd }}$ Edition. American Fisheries Society, Bethesda, Maryland.

Heidinger, R. C. 1975. Life History and Management of the Largemouth Bass. Pages 11-20 in H. Clepper, editor. Black bass biology and management. Sport Fishing Institute, Washington, D.C. 
Horak, D. 1995. Native and Nonnative Fish Species Used in State Fisheries Management Programs in the United States. Pages 61-70 in Schramm and Piper, editors. Uses and Effects of Cultured Fishes in Aquatic Ecosystems. American Fisheries Society, Bethesda, Maryland.

Jenkins, R. E. , and N. M. Burkhead, Freshwater Fishes of Virginia. 1994. American Fisheries Society, Bethesda, Maryland.

Keith, W. E. 1975. Management by Water Level Manipulation. Pages 489-497 in H. Clepper, editor. Black bass biology and management. Sport Fishing Institute, Washington, D.C.

Kieffer, J. D., M. R. Kubacki, F. J. S. Phelan, D. P. Phillipp, and B. L. Tufts. 1995. Effects of Catch-and-Release Angling on Nesting Male Smallmouth Bass. Transactions of the American Fisheries Society 124:70-76.

Kinman, B. 1995. Use of Cultured Fish for Put-Grow-and-Take Fisheries in Kentucky Impoundments. Pages 518-526 in R. H. Stroud, editor. Fish culture in fisheries management. American Fisheries Society, Fish Culture Section and Fisheries Management Section, Bethesda, Maryland.

Killgore, J. K., R. P. Morgan II, and N. B. Rybicki. 1989. Distribution and Abundance of Fishes Associated with Submersed Aquatic Plants in the Potomac River. North American Journal of Fisheries Management 9:101-111.

Kramer, R. H., and L. L. Smith. 1960. First-year growth of the largemouth bass, Micropterus salmoides (Lacepede), and some related ecological factors. Transactions of the American Fisheries Society. 89(1):19-41. 
Lang, R. E., G. C. LeTendre, T. H. Eckert, and C. P. Schneider. 1995. Enhancement of Sportfishing in New York Waters of Lake Ontario with Hatchery-Reared Salmonides. Pages 7-11 in R. H. Stroud, editor. Fish culture in fisheries management. American Fisheries Society, Fish Culture Section and Fisheries Management Section, Bethesda, Maryland

Larscheid, J., J. Christianson, T. Gengerke, and W. Jorgensen. 1999. Survival, Growth, and Abundance of Pellet-Reared and Minnow-Reared Muskellunge Stocked in Norhtwestern Iowa. North American Journal of Fisheries Management 19:230-237.

Lassuy, D. R. 1995. Introduced Species as a Factor in Extinction and Endangerment of Native Fish Species. Pages 391-398 in R. H. Stroud, editor. Fish culture in fisheries management. American Fisheries Society, Fish Culture Section and Fisheries Management Section, Bethesda, Maryland.

Lawson, C. S., and W. D. Davies. 1977. Effects of Bass Stocking and Rates of Fishing on a Largemouth Bass Population. Proc. Annual Conf. S.E. Assoc. Fish and Wildlife Agencies 31:493-497

Leary, R. F., F. W. Allendorf, and G. K. Sage. 1995. Hybridization and Introgression between Introduced and Native Fish. Pages 91-101 in R. H. Stroud, editor. Fish culture in fisheries management. American Fisheries Society, Fish Culture Section and Fisheries Management Section, Bethesda, Maryland.

Lee, D. P. 1995. Contribution of Nonnative Fish to California's Inland Recreational Fishery. Pages 16-20 in R. H. Stroud, editor. Fish culture in fisheries management. American Fisheries Society, Fish Culture Section and Fisheries Management Section, Bethesda, Maryland. 
Lewis W. M., and S. A. Flickinger. 1967. Home Range Tendency of the Largemouth Bass (Micropterus Salmoides). Ecology, Vol. 48, No. 6.

Loska, P. M. 1982. A Literature Review on the Stocking of Black Basses (Micropterus spp.) in Reservoirs and Streams. Georgia Department of Natural Resources, Game and Fish Division. Study SW-1 Atlanta, Georgia.

MacCrimmon, H. R., and W. H. Robbins. 1975. Distribution of the Black Basses in North America. Pages 56-66 in in H. Clepper, editor. Black bass biology and management. Sport Fishing Institute, Washington, D.C.

Marler, B. J., and D. C. Jackson. 1992. Population Characteristics of Largemouth Bass in Riverine Sections of the Tennessee-Tombigbee Waterway. Proc. Annu. Conf. Southeast. Assoc. Fish and Wildl. Agencies 46:386-392

Marnel, L. F. 1986. Impacts of Hatchery Stocks on Wild Fish Populations. Pages 339347 in R. H. Stroud, editor. Fish culture in fisheries management. American Fisheries Society, Fish Culture Section and Fisheries Management Section, Bethesda, Maryland McGurrin, J., C. Ubert, and D. Duff. 1995. Use of Cultured Salmonids in the Federal Aid in Sport Fish Restoration Program. Pages 12-15 in R. H. Stroud, editor. Fish culture in fisheries management. American Fisheries Society, Fish Culture Section and Fisheries Management Section, Bethesda, Maryland

Ming, A., and W. E. McDonnald. 1975. Effects of Length Limit on an Overharvested Largemouth Bass Population. Pages 416-424 in in H. Clepper, editor. Black bass biology and management. Sport Fishing Institute, Washington, D.C. 
Murphy, B. R., and W. E. Kelso. 1986. Strategies for Evaluating Fresh-Water Stocking Programs: Past Practices and Future Needs. Pages 303-313 in R. H. Stroud, editor. Fish culture in fisheries management. American Fisheries Society, Fish Culture Section and Fisheries Management Section, Bethesda, Maryland.

Nack, S. B., D. Bunell, D. M. Green, and J. L. Forney. 1993 Spawning and Nursery Habitats of Largemouth Bass in the Tidal Hudson River. Transactions of the American Fisheries Society 122:208-216.

Olson, M. H. 1996. Ontogenetic Niche Shifts in Largemouth Bass: Variability and Consequences for First-Year Growth. Ecology, 77(1): 179-190.

Olver, C. H., B.J. Shuter, and C.K. Minns. 1995. Toward a definition of conservation principles for fisheries management. Canadian Journal of Fisheries and Aquatic Sciences 52:1584-1595.

Phillipp, D. P., and J. E. Claussen. 1995. Fitness and Performance Differences between Two Stocks of Largemouth Bass from Different River Drainages within Illinois. Pages 236-243 in R. H. Stroud, editor. Fish culture in fisheries management. American Fisheries Society, Fish Culture Section and Fisheries Management Section, Bethesda, Maryland.

Pine, W. E., S. A. Ludsin, and D. R. DeVries. 2000. First-Summer Survival of Largemouth Bass Cohorts: Is Early Spawning Really Best? Transactions of the American Fisheries Society 129:504-531.

Pitlo, J., Jr. 1992. An evaluation of largemouth bass populations in the upper Mississippi River. Iowa Department of Natural Resources, Federal Aid in Sport Fish Restoration, Project F-109-R, Final Report, Des Moines. 
Radonski, G. C., and A. J. Loftus. 1995. Keynote Address: Fish Genetics, Fish Hatcheries, Wild Fish, and Other Fables. Pages 1-6 in R. H. Stroud, editor. Fish culture in fisheries management. American Fisheries Society, Fish Culture Section and Fisheries Management Section, Bethesda, Maryland.

Rahel, F. J., R. T. Muth, and C. A. Carlson. 1999. Endangered Species Management. Pages 431-451in Kohler, editor. Inland Fisheries Management in North America, $2^{\text {nd }}$ Edition. American Fisheries Society, Bethesda, Maryland.

Raibley, P. T., K. S. Irons, T. M. O’Hara, K. D. Blodgett, and R. E. Sparks. 1997. Winter Habitats Used by Largemouth Bass in the Illinois River, a Large River-Floodplain Ecosystem. North American Journal of Fisheries Management 17:401-412

Ramsey, J. S. 1975. Taxonomic History and Systematic Relationships Among Species of Micropterus. Pages 67-75 in H. Clepper, editor. Black bass biology and management. Sport Fishing Institute, Washington, D.C.

Reisenbichler, R. R., and J. D. McIntyre. 1977. Genetic Differences in Growth and Survival of Juvenile Hatchery and Wild Steelhead Trout, Salmo gairdneri. J. Fish. Res. Board Can. 34: 123-128.

Ross, Stephen T. 1991. Mechanisms structuring stream fish assemblages: are there lessons from introduced species? Environmental Biology of Fishes 30: 359-368.

Ryan, M. J., M. A. Webb, and L. T. Fries. 1996. Contribution of Largemouth Bass Reared in Nursery Ponds to Year Classes in Two Texas Reservoirs. Proc. Annu. Conf. Southeast. Assoc. Fish and Wildl. Agencies 50:131-138. 
Sammons, S. M., L. G. Dorsey, and P. W. Bettoli. 1999. Effects of Reservoir Hydrology on Reproduction by Largemouth Basss and Spotted Bass in Normandy Reservoir, Tennessee. North American Journal of Fisheries Management 19:79-88.

Satterfield, J. R., and S. A. Flickinger. 1986. Use of Yearling Largemouth Bass for Initial Stocking of Small Impoundments. Pages 375-380 in R. H. Stroud, editor. Fish culture in fisheries management. American Fisheries Society, Fish Culture Section and Fisheries Management Section, Bethesda, Maryland

Savitz, J., P. A. Fish, and R. Weszely. 1983. Effects of Forage on Home-Range Size of Largemouth Bass. Transactions of the American Fisheries Society 112:772-776.

Sheaffer, W. A., and J. G. Nickum. 1986. Backwater areas as nursery habitats for fishes in Pool 13 of the Upper Mississippi River. Hydrobiologia 136: 131-140.

Sheehan, R. J., and J. L. Rasmussen. 1999. Large Rivers. Pages 521-559 in C.C. Kohler, and W.A. Hubert editors. Inland Fisheries Management in North America, $2^{\text {nd }}$ Edition. American Fisheries Society, Bethesda, Maryland.

Smith, B. W., and W. C. Reeves. 1986. Stocking Warm-Water Speicies to Restore or Enhance Fisheries. Pages 17-29 in R. H. Stroud, editor. Fish culture in fisheries management. American Fisheries Society, Fish Culture Section and Fisheries Management Section, Bethesda, Maryland.

Snow, H. E. 1978. Responses of northern pike exploitation in Murphy Flowage, Wisconson. Spec. Pulb. 11:320-327. American Fisheries Society, Bethesda, Maryland.

Snow, J. R. 1968. Production of six to eight inch largemouth bass for special purposes. The Progressive Fish-Culturist, 30:144-152. 
Stone, M. D. 1995. Fish Stocking Programs in Wyoming: A Balanced Perspective. Pages 47-51 in R. H. Stroud, editor. Fish culture in fisheries management. American Fisheries Society, Fish Culture Section and Fisheries Management Section, Bethesda, Maryland.

Storck, T. W. 1986. Importance of Gizzard Shad in the Diet of Largemouth Bass in Lake Shelbyville, Illinois. Transactions of the American Fisheries Society 115:21-27.

Summerfelt, R. C. 1975. Relationship Between Weather and Year-Class Strength of Largemouth Bass. Pages 166-174 in H. Clepper, editor. Black bass biology and management. Sport Fishing Institute, Washington, D.C.

Terre, D. R., S. J. Magnelia, and M. J. Ryan. 1993. Year Class Contribution of Genetically-marked Florida x Northern Largemouth Bass Stocked in Three Texas Reservoirs. Proc. Annu. Conf. Southeast. Assoc. Fish and Wildl. Agencies 47:622-632.

Trautman, Milton B. The Fishes of Ohio. 1981. Ohio State University Press.

Waldman, J.R., and I.I. Wirgin. June 1998. Status and Restoration Options for Atlantic Sturgeon in North America. Conservation Biology, Pages 631-638, Volume 12, No. 3 .

White, R. J., J. R. Karr, and W. Nehlsen. 1995. Better Roles for Fish Stocking in Aquatic Resources Management. Pages 527-550 in Schramm and Piper, editor. Uses and Effects of Cultured Fishes in Aquatic Ecostystems. American Fisheries Society, Bethesda, Maryland. 


\title{
CHAPTER 2:
}

\section{Evaluation of Tag Retention and Delayed Post-Stocking Mortality in Adult and Intermediate Hatchery Reared Largemouth Bass}

\author{
Abstract \\ A two-year study was conducted by West Virginia University to evaluate the return to \\ creel, movements, and persistence of largemouth bass stocked into two Ohio River embayments. \\ Prior to stocking, each fish was fitted with an anchor tag as well as a visible implant elastomer \\ (VIE) mark. As part of that larger study, we sought to: (1) monitor anchor tag retention, and VIE \\ detection, (2) estimate delayed mortality of hatchery-reared largemouth bass resulting stresses \\ associated with stocking, and (3) to compare mortality and tag loss rates between adult and \\ intermediate size largemouth bass. \\ Post-handling survival of the randomly selected, tagged largemouth bass was found to be \\ $73.5 \%$ and $42.9 \%$ for intermediate and adult size-classes held in hatchery ponds over a 31 day \\ period, respectively. Data indicated that tag loss of anchor tags was negligible for both size \\ classes over this time period, and detection of VIE marks was $97.9 \%$ and $98.4 \%$ in adult and \\ intermediate largemouth bass, respectively. Long-term (207-600 days at large) retention and \\ detection of VIE marks appeared to be substantially higher (83.3\% compared to $38.5 \%$ in anchor \\ tags) than that of anchor tags. Both the results of the short-term retention study conducted in \\ hatchery ponds, and retention rates estimated from the recapture of double-tagged fish following \\ stocking indicate that detection rates of fish tagged in this manner are sufficient to provide \\ fishery statistics in largemouth bass for up to six months. However, the relatively high levels of
}


mortality indicate that alternative methods of tagging and handling, as well as sources of obtaining and hauling fish should be investigated in order to minimize delayed mortality.

\section{Introduction}

Fish tagging and marking techniques are essential tools for fisheries biologists evaluating the use of cultured fish (Hilborn et al. 1990; Buckmeier and Irwin 2000). Estimating survival of stocked fish is the most common and basic post-stocking evaluation method (Murphy and Kelso 1986). Mark and recapture methodology can be used to provide a direct estimate of poststocking mortality (Buynak et al. 1999; Buynak and Mitchell 1999), or survival can be evaluated indirectly by measuring return to creel of stocked fish (Murphy and Kelso 1986). The ability to differentiate hatchery-reared fish from wild conspecifics is essential in monitoring survival, return to creel, and movement of stocked fish after their release (Hilborn et al. 1990).

A primary assumption associated with fish tagging programs is that tag loss is negligible and tagged fish are recognized and reported as such (Guy et al. 1996). Although various marking techniques differ in their retention characteristics, no method of externally tagging or marking fish provides 100 percent retention. The ability to estimate shedding rates of a specific tagging method are required in order to adjust survival estimates that depend on the recapture of marked individuals (Fabrizio et al. 1996). If not adjusted to compensate for tag loss, survival rates of stocked fish can be greatly underestimated (Guy et al. 1996).

Post-stocking survival evaluations of hatchery-reared fish based upon tag returns assume that the presence of tags or marks, as well as stress inflicted through handling have a minimal effect on the behavior and health of the fish (Tranquilli and Childers 1982). Most fish become stressed when they are captured, handled, tagged, or stocked into another body of water. The effects of this stress can lead to heightened disease susceptibility, and ultimately to death 
(Carmichael et al. 1984). It is advantageous for managers to be able to discern between mortality resulting from handling and tagging procedures and natural (predation, starvation, ect.) poststocking mortality. Knowing the effects of specific tagging and handling methods on immediate mortality is helpful so post-stocking survival estimates, as well as stocking rates can be adjusted to compensate for this mortality. This knowledge can also help fisheries professionals improve techniques and methods used to tag and handle fish. Immediate and delayed mortality of cultured fish due to hauling and tagging procedures can bias post-stocking evaluations and lead to inaccurate stocking rates. Tag retention and handling mortality may also be influenced by fish size (Dussault and Rodriguez 1997), which could lead to bias when more than one size class of hatchery fish are being evaluated.

Anchor tags have been in use since 1968 (McFarlane et al. 1990), and have been used on a number of species, including largemouth bass, with varying results (Wilbur and Duchrow 1973; Tranquilli and Childers 1982; Muoneke 1992; Rikardsen 2000). Advantages of anchor tags include the ability to identify individual fish, provide return and reward information to anglers, and ease of tagging. Wilbur and Dutchrow (1973) tested retention of five different types of Floy ${ }^{\circledR}$ anchor tags in largemouth bass and found that three-month retention ranged from $47 \%$ to $88 \%$, depending on the model of Floy ${ }^{\circledR}$ tag used. The reinforced (FD-68B) anchor tags were found to be superior to the other models tested (Wilbur and Dutchrow 1973). Tranquilli and Childers (1982) concluded that the use of Floy anchor tags (FD-68B) had no effect on survival, growth, and condition of largemouth bass. The information from these two studies suggest that the use of Floy ${ }^{\circledR}$ (FD-68B) anchor tags can be used to provide reliable estimates of fishery statistics in largemouth bass populations for up to a three month period (Wilbur and Dutchrow 1973; Tranquilli and Childers 1982). 
Northwest Marine Technology ${ }^{\circledR}$, Inc. (NWMT) developed a method of batch marking fish using a visible implant elastomer (VIE) mark. The VIE mark is injected as a fluorescent liquid polymer into transparent tissue areas of the study organism where it solidifies after injection (Bailey et al. 1998). Evaluations of retention and recognition of VIE tags in fish have produced mixed results depending on the species, as well as tag location and elastomer color (Dewey and Zigler 1996; Bailey et al. 1998; Haines et al. 1998; Hale and Gray 1998). Close (2000) reported that VIE marks became undetectable over a 186 day observation period in adipose tissue of fingerling rainbow trout (Oncorhynchus mykiss). Reduction in delectability of VIE marks in this study was attributed to fish growth. Bailey et al. (1998) reported a 73\% detection rate after two years in postocular marked coho salmon (O. kisutch) smolt, and Dewey and Zigler (1996) reported 99\% retention in bluegills marked in various locations after a 6-month period. Neither tagging location, nor mark retention of VIE tags used for batch marking largemouth bass have been evaluated.

On October 20, 1998 the West Virginia Division of Natural Resources stocked adult and intermediate hatchery reared largemouth bass into two embayment areas of the Ohio River. A two-year study was conducted by West Virginia University to evaluate the return to creel, movements, and persistence of these hatchery-reared largemouth bass in the Ohio River (Chapter 3). Each largemouth bass was fitted with a Floy ${ }^{\circledR}$ (FD-68B) anchor tag bearing a unique, nonsequential identification number along with a contact name and telephone number prior to stocking. A VIE mark was also injected into the anal fin of each fish as a backup in the event that the anchor tag was lost during the course of the study.

The purpose of this study was to: (1) monitor retention of Floy ${ }^{\circledR}$ anchor tags (FD-68B) and VIE marks in adult and intermediate sized largemouth bass in order to adjust post-stocking 
survival estimates that depend on the recapture of marked individuals, (2) estimate immediate and delayed mortality of hatchery-reared largemouth bass resulting from hauling and tagging procedures, and (3) to compare mortality and tag loss rates between adult and intermediate size largemouth bass. The results of this study were used to address tag loss and mortality due to handling when evaluating survival and return to creel of cultured largemouth bass stocked into Ohio River embayment areas (Chapter 3).

\section{Materials and Methods}

Largemouth bass used in this study were purchased from a private aquaculture vendor. These fish were reared on a pellet diet in hatchery ponds and purchased at a cost of $\$ 3.50$ and $\$ 5.00$ per fish for intermediate and adult fish, respectively. The adult size class (mean total length, MTL, $=273 \mathrm{~mm}$ ) used for stocking were spawned in May 1997, and the intermediate size $(\mathrm{MTL}=178 \mathrm{~mm})$ in May 1998. Prior to delivery, largemouth bass were hauled and handled according to suggestions outlined in Carmichael et al. (1984), in an attempt to minimize hauling stress. These suggestions included: not feeding the fish for two days prior to hauling; hauling fish in a saltwater solution $(0.5-1.0 \% \mathrm{NaCl})$; and hauling fish under a mild anesthetic $\left(\mathrm{CO}_{2}\right)$ in cool water temperatures.

Personnel from the West Virginia Division of Natural Resources and West Virginia University conducted tagging procedures at Palestine State Fish Hatchery, West Virginia on 20 October 1998. Prior to being tagged, hatchery largemouth bass were anesthetized in a clove oil solution (1.2 $\mathrm{ml}$ per 20L of $\mathrm{H}_{2} \mathrm{O}$ as described by Peake, 1998) to minimize handling stress. Fish were tagged using a Floy ${ }^{\circledR}$ Mark II tagging gun equipped with a $27-\mathrm{mm}$ needle. The anchor tags were inserted at the base of the dorsal fin at a $45^{0}$ angle, so the anchor end of the tag locked 
behind the pterygiophores of the fish (Tranquilli and Childers 1982). Once the tag was in place, the applicator was twisted $90^{\circ}$ to dislodge the tag (Guy et al. 1996). Next, the tags were gently tugged upon to ensure proper attachment. If the tag was determined to be loose or was not retained on the initial tagging attempt, then that fish was considered untagged when calculating initial tagged percentages. No additional attempts to retag were made out of concern for potential increased mortality (Guy et al. 1996). These "untagged" fish represented 3.5 and 7.0 percent of all intermediate $(\mathrm{N}=3,288)$ and adult $(\mathrm{N}=1,249)$ size, stocked largemouth bass, respectively.

After reviewing past VIE retention studies (Bailey et at. 1998, Haines et at. 1998, Hale and Grey 1998) and experimenting with various tagging locations in largemouth bass, the interstitial space between anal fin rays was chosen for VIE tags (Figure 1). This area was chosen based upon the ease of tagging and the high visibility of the mark at this location. Separate elastomer colors (red, green, yellow, and orange) were assigned to the different size class and study site batches. Elastomer tags were implanted using air driven injector systems provided by Northwest Marine Technologies, Inc. The tagging needle was placed into the soft connective tissue between anal fin rays and inserted to the base of the anal fin. Elastomer was injected in a straight line (parallel to the anal fin ray) as the tagging needle was withdrawn. Care was taken to end the mark before the hypodermic needle was withdrawn to reduce the chance of a percutaneous condition that can lead to increased tag loss (personal communication, Mary Woodgate, Northwest Marine Technologies Inc.). Next, weight (nearest gram), total length (nearest millimeter), and unique identification tag numbers were recorded for each fish. Using four tagging and processing stations, 4,537 largemouth bass were measured, weighed, and fitted with anchor tags as well as VIE marks in less than seven hours. 
Fish were tagged in batches based upon size class and which embayment they were to be stocked. After tagging was completed for each batch, the fish were hauled from Palestine Fish Hatchery to the study areas via West Virginia Division of Natural Resources stock trucks. The largemouth bass were unloaded from the hatchery trucks at the study site and loaded into boat live wells provided by local anglers. They were then transported by boat to the middle of their respective embayment areas and released. Combined delivery and post-tagging transport time of hatchery fish were somewhere between eight and nine hours depending on which embayment they were stocked. Visual observations were conducted daily at each study site for two days following the stocking to monitor for signs of immediate post-stocking mortality. No indication of immediate post-stocking mortality was observed during tagging or stocking procedures, or during post stocking surveys.

To evaluate delayed (31 day) post-handling mortality and short-term tag retention, a random sample of largemouth bass was selected after tagging procedures were completed from each size and stocking location batch. These fish were placed into two one-acre ponds at Palestine State fish hatchery. Adult fish $(\mathrm{N}=219)$ were placed in one pond, and intermediate sized $(\mathrm{N}=196)$ fish into another to prevent predation of the smaller size class. Fathead minnows (Pimephales promelas) were stocked into the ponds to provide a food source for the largemouth bass over the course of the study. Personnel from Palestine State Fish Hatchery conducted weekly observations around both ponds to look for largemouth bass carcasses and to collect tag information from dead fish. Both ponds were drained on November 20, 1998 and all remaining fish were collected and observed for tag retention, VIE detection, and mortality.

Survival rates between the adult and intermediate size classes were compared using a chisquare test modified by applying the Yates (1934) correction for continuity (Zar 1999). VIE 
mark detection between the adult and intermediate size classes were compared using Fisher's exact test instead of a chi-square. Fisher's exact test has been shown to be preferable to chisquare when frequencies are small as was the case with the loss of VIE marks (Zar 1999).

Long term retention rates of both marking methods were evaluated on largemouth bass released into two Ohio River embayments by comparing the number of stocked fish recaptured during electrofishing surveys and at black bass tournaments (Chapter 3) still bearing both marking types to the number bearing only one. For example, tag loss rate for tag $\mathrm{A}\left(\Pi_{A}\right)$ was estimated by $\Pi_{A}=\mathrm{R}_{\mathrm{B}} /\left(\mathrm{R}_{\mathrm{B}}+\mathrm{R}_{\mathrm{AB}}\right)$; where $\mathrm{R}_{\mathrm{B}}$ were the recoveries of fish with tag $\mathrm{B}$ only, and $\mathrm{R}_{\mathrm{AB}}$ were the recoveries of fish with both tag types still intact (Eames and Hino 1983). The variance of $\Pi_{A}$ was estimated by $\Pi_{A}\left(1-\Pi_{A}\right) /\left(\mathrm{R}_{\mathrm{B}}+\mathrm{R}_{\mathrm{AB}}-1\right)$. In some instances tag retention data collected over a series of dates were pooled in order obtain larger sample sizes. In these instances, a weighted average was used to estimate days post-tagging.

\section{Results}

Although steps were taken to minimize handling time and stress associated with hauling and tagging procedures, considerable mortality was observed in the largemouth bass held in hatchery ponds for 31 days. Adult largemouth bass exhibited a significantly higher mortality rate than the intermediate size class (Chi-square with continuity adjustment, $\mathrm{p}=0.0007$ ). Posthandling survival of the randomly selected, tagged largemouth bass was found to be $73.5 \%$ and 42.9\% for intermediate and adult size-classes held in hatchery ponds over a 31 day period, respectively (Table 1). Hatchery personnel only discovered 22 largemouth bass carcasses after the ponds were drained or while conducting weekly walk-around observations. These observed carcasses accounted for only $15 \%$ of total mortality losses. 
Short-term (31 day) retention of the Floy ${ }^{\circledR}$ (FD-68B) tags was excellent. The ability to successfully tag largemouth bass with Floy ${ }^{\circledR}$ (FD-68B) anchor tags on the initial attempt ranged from $96.7 \%$ for the intermediate size class to $93.1 \%$ in the adult size class. Of the largemouth bass randomly selected for the short-term mortality/tag retention study, immediate loss of anchor tags was $2.6 \%$ and $7.3 \%$ for the intermediate and adult size classes, respectively (Table 2). Thus, due to the fact that no additional attempts were made to re-tag fish in the event that the initial attempt was unsuccessful, a small portion of the randomly selected largemouth bass did not receive anchor tags. When the hatchery ponds were drained on November 30, 1998 (31 days at large), it was found that $97.2 \%$ and $93.6 \%$ of surviving intermediate and adult largemouth bass retained anchor tags, respectively (Table 2). These data indicate that tag loss of Floy ${ }^{\circledR}$ (FD-68B) anchor tags was negligible for both size classes of largemouth bass held in hatchery ponds for one-month.

Short-term retention of VIE marks was also found to be very high in the largemouth bass held in hatchery ponds. Detection of VIE marks was observed in $97.9 \%$ and $98.4 \%$ of adult and intermediate largemouth bass held in hatchery ponds for 31 days. No significant difference was found to exist between VIE retention rates of the adult and intermediate sizes class held for a one month period $(\mathrm{p}=0.7697)$.

Long-term tag retention of largemouth bass stocked into Ohio River embayment areas was estimated for four different time intervals over the course of the study (Table 3). Estimated anchor tag and VIE mark retention rates of largemouth bass released into Ohio River embayments were found to be very high during the first several months at liberty (Table 3). Long-term (recaptured between 207 - 600 days at liberty) retention and detection of VIE marks appeared to be substantially higher than that of anchor tags. VIE retention for this time interval 
was estimated at $83.3 \%$ compared to $38.5 \%$ for anchor tag retention. Although there was no detectible difference between short-term (31d) retention of the two marking methods, long term (type-II) shedding rates were found to be substantially lower for VIE marks. Although recapture dates were pooled in order to obtain adequate sample sizes, delectability of VIE marks to 429 days at large (weighted average) was estimated to be greater than $80 \%$ while retention of anchor tags for the same period was only estimated to be 39\%. Type-II shedding losses of VIE marks were lower than those of anchor tags for all four recapture periods in which a retention estimate was obtained (Table 3).

\section{Discussion}

Short-term retention of VIE marks, as well as Floy ${ }^{\circledR}$ tags was excellent in both intermediate and adult sized largemouth bass. Short-term (type-I shedding) loss of VIE marks was presumed to be a result of the elastomer being expelled before the initial entry wound had the opportunity to heal. We measured type-I shedding of VIE marks in randomly selected, marked largemouth bass placed into hatchery ponds for 31days. This type of shedding was found to be minimal (less than 3\%) in both size classes tested. Although adult largemouth bass tended to be easier to mark than intermediates, we found no significant difference between VIE detection rates of the two size classes after one month. Other researchers have suggested that a positive relationship between increased size and VIE mark retention may exist (Hale and Grey 1998; Close 2000), but our data did not indicate such a relationship between the two size classes studied. Immediate shedding of anchor tags was less than $7 \%$ in both the intermediate and adult size classes. This type of shedding usually occurred as tags were tugged to ensure proper attachment, or when tags became tangled in dipnets during stocking. Short-term (type-I) 
shedding of anchor tags was found to be negligible in both size classes of largemouth bass randomly selected and placed into hatchery ponds for a 31d period.

Also, no call-in reports of tagged largemouth bass were reported after May 1999 (6 months at liberty) (Chapter 3) providing additional evidence that loss of anchor tags may have been high after several months. Combined data from this study suggest that anchor tags used in this fashion may not be reliable past six months for largemouth bass. Although anchor tags provide the advantage of bearing individual identification numbers, and providing tag return data to anglers, we found that readability became difficult as time increased due to the combined effects of wear and algal growth obscuring tag numbers and return information.

Although no immediate mortality of hatchery-reared largemouth bass was observed, results of the delayed mortality study suggest that substantial delayed mortality occurred in stocked largemouth bass. It also points out that although largemouth bass may appear to be in good health at the time of their release, delayed mortality resulting from handling/hauling or nutritional deficiencies can be substantial and if not taken into consideration, can confound post stocking evaluation efforts.

Although Tranquilli and Childers (1982) reported that the use of Floy ${ }^{\circledR}$ anchor tags did not negatively affect growth or mortality rates of tagged largemouth bass, mortality rates we observed indicate substantial mortality over a one-month period. Post release mortality of stocked fish has been shown to increase with hauling distance (Pitman and Gutreuter 1993), and Carmichael et al. (1984) reported delayed mortality resulting from stress associated with hauling. Unfortunately, our study design did not allow us to discern what portion of observed mortality resulted from handling/tagging procedures compared to hauling or other factors. It is possible that a portion of the observed mortality resulted from predation by wading birds based upon 
hatchery personel observations (Tim Swisher WVDNR, personnel communication). Our data indicate that largemouth bass in the intermediate size range $(\mathrm{MTL}=178)$ had higher initial survival than the adult size class $(\mathrm{MTL}=273)$.

The use of pellet feed has increased the availability and lowered costs associated with producing large numbers of advanced sized largemouth bass (Satterfield and Flickinger 1986), but research has indicated that pellet reared fish may be less viable than those reared on a minnow diet (Larscheid et al. 1999). The majority of tagged largemouth bass recaptured the first month following stocking (as well as those examined after hatchery ponds were drained) exhibited high levels of fungal infections and appeared to be in poor health. Deformities of the lower jaw were prevalent in recaptured, tagged bass. Nutritional problems (vitamin C deficiency), including deformities of the lower jaw, have been evident with pellet-reared largemouth bass (personal communication, Wes Porak, Florida Fish and Wildlife Conservation Commission), as well as other hatchery-reared species (Colesante and Bubnack 1993; Jorgensen 1994). Further study is needed to compare delayed handling/tagging mortality between largemouth bass reared on natural diets to those raised on artificial feed in order to evaluate the costs and benefits of each rearing method. Although pellet reared fish are cheaper to raise, this maybe offset by poor post stocking survival.

The results of this study allowed us to adequately address the validity of major assumptions associated with our tagging program. Both the results of the short-term retention study conducted in hatchery ponds, and retention rates estimated from the recapture of doubletagged fish indicate that detection of fish tagged in this manner is sufficient to provide fishery statistics in largemouth bass past six months. Delayed mortality rates were quantified for this 
particular stocking method and used to adjust stocking densities when evaluating the success of the stocking program. 


\section{Literature Cited}

Bailey, R. E., J. R. Irvine, F. C. Dalziel, and T. C. Nelson. 1998. Evaluations of Visible Implant Fluorescent Tags for Marking Coho Salmon Smolts. North American Journal of Fisheries Management 18:191-196

Buckmeier, D. L., and E. R. Irwin. 2000. An Evaluation of Soft Visual Implant Tag Retention Compared with Anchor Tag Retention in Channel Catfish. North American Journal of Fisheries Management 20:296-298.

Buynak, G. L., and B. Mitchell. 1999. Contribution of Stocked Advanced-fingerling Largemouth Bass to the Population and Fishery at Taylorsville Lake, Kentucky. North American Journal of Fisheries Management 19:494-503.

Buynak, G. L., B. Mitchell, D. Michaelson, and K. Frey. 1999. Stocking Subadult Largemouth Bass to Meet Angler Expectations at Carr Creek Lake, Kentucky. North American Journal of Fisheries Management 19:1017-1027.

Carmichael, G. J., J. R. Tomasso, B. A. Simco, and K. B. Davis. 1984. Characterization and Alleviation of Stress Associated with Hauling Largemouth Bass. Transactions of the American Fisheries Society 113:778-785.

Close, T. L. 2000. Detection and Retention of Postocular Visible Implant Elastomer in Fingerling Rainbow Trout. North American Journal of Fisheries Management 20:542545.

Colesante, R. T., and J. Bubnack. 1993. Deformitities in Chautauqua muskellunge reared on artificial diets. Proceedings of the Coolwater Fish Culture Workshop, Spirit Lake, Iowa. 
Dewey, M. R., and S. J. Ziegler. 1996. An evaluation of fluorescent elastomer for marking bluegills in experimental studies. Progressive Fish-Culturist 58:219-220.

Dussault, C., and M. A. Rodriguez. 1997. Field Trials of Marking Stream Salmonids by Dye Injection and Coded-Wire-Tagging. North American Journal of Fisheries Management 17:451-456.

Eames, M. J., and M. K. Hino. 1983. An evaluation of four tags suitable for marking juvenile Chinook salmon. Transactions of the American Fisheries Society 112;464-468.

Fabrizio, M. C., B. L. Swanson, S. T. Schram, and M. H. Hoff. 1996. Comparison of Three Nonlinear Models to Describe Long-Term Tag Shedding by Lake Trout. Transactions of the American Fisheries Society 125:261-273.

Guy, C. S., H. L. Blankenship, and L. A. Nielsen. 1996. Tagging and Marking. Pages 353-379 in Murphy, editor. Fisheries Techniques, $2^{\text {nd }}$ edition. American Fisheries Society, Bethesda, Maryland.

Haines, G. B., S. H. Severson, and T. Modde. 1998. Evaluation of Razorback Sucker and Colorado Squawfish Batch Marking Techniques. The Progressive Fish-Culturist 60:272-275.

Hale, R. S., and J. H. Gray. 1998. Retention and Detection of Coded Wire Tags and Elastomer Tags in Trout. North American Journal of Fisheries Management 18:197-201.

Hilborn, R., C. J. Walters, and D. B. Jester, Jr. 1990. Value of Fish Marking in Fisheries Management. Pages 5-8 in, Parker et al., editor. Fish Marking techniques. American Fisheries Society Synmposium 7. Bethesda, Maryland.

Jorgensen, W. D. 1994. Spirit Lake Hatchery production report. Iowa Department of Natural Resources, Fish Culture Section, Completion Report, Des Moines. 
Larscheid, J., J. Christianson., T. Gengerke, and W. Jorgensen. 1999. Survival, Growth, and Abundance of Pellet-Reared and Minnow-Reared Muskellunge Stocked in Northwestern Iowa. North American Journal of Fisheries Management 19:230-237.

McFarlane, G. A., R. S. Wydoski, and E. D. Prince. 1990. Historical Review of the Development of External Tags and Marks. Pages 9-29 in, Parker et al., editor. Fish Marking techniques. American Fisheries Society Synmposium 7. Bethesda, Maryland.

Muoneke, M. I. 1992. Loss of Floy Anchor Tags from White Bass. North American Journal of Fisheries Management 12:819-824.

Murphy, B. R., and W. E. Kelso. 1986. Strategies for Evaluating Fresh-Water Stocking Programs: Past Practices and Future Needs. Pages 303-313 in R. H. Stroud, editor. Fish culture in fisheries management. American Fisheries Society, Fish Culture Section and Fisheries Management Section, Bethesda, Maryland.

Peake, S. 1998. Sodium Bicarbonate and Clove Oil as Potential Anesthetics for Nonsalmonid Fishes. North American Journal of Fisheries Management 18:919-924.

Pitman, V. M., and S. Gutreuter. 1993. Initial Poststocking Survival of Hatchery-Reared Fishes. North American Journal of Fisheries Management 13:151-159.

Rikardsen, A. H. 2000. Effects of Floy and Soft VIalpha Tags on Growth and Survival of Juvenile Arctic Char. North American Journal of Fisheries Management 20:720-729.

Satterfield, J. R., Jr., and S. A. Flickinger. 1986. Use of yearling largemouth bass for initial stocking of small impoundments. Pages 375-380 in R. H. Stroud, editor. 
Tranquilli, J. A., and W. F. Childers. 1982. Growth and Survival of Largemouth Bass Tagged with Floy Anchor Tags. North American Journal of Fisheries

Fish culture in fisheries management. American Fisheries Society, Fish Culture Section and Fisheries Management Section, Bethesda, Maryland.

Management 2:184-1.

Wilbur, R. L., and R. M. Duchrow. 1973. Differential retention of five Floy tags on largemouth bass (Micropterus salmoides) in hatchery ponds. Proceedings of the Annual Conference Southeastern Association of Game and Fish Commissioners 26(1972):407-413 
Table 1. Post-handling/hauling mortality in a randomly selected experimental group held in hatchery ponds for 31 days

\begin{tabular}{l|cc}
\hline \multicolumn{2}{c}{ Adult (MTL = 273) } & Intermediate (MTL = 178) \\
\hline & 219 & 196 \\
Original sample size & & 144 \\
Number of fish alive after \\
31 days at liberty
\end{tabular}


Table 2. Retention and detection rates of Floy tags and visible implant elastomer marks in randomly selected experimental groups held in hatchery ponds for 31 days.

Adult (MTL 273) Intermediate $($ MTL $=178)$

Sample size

Percent of sample with an intact anchor

tag at the start of experiment.

Percent of surviving fish with intact anchor tag after 31 days at liberty

VIE mark retention after 31 days at liberty.
219

196

$92.7 \%$

$97.4 \%$

$93.6 \%$

$97.2 \%$

$98.4 \%$

$97.9 \%$ 
Table 3. Estimated retention and detection rates in recaptured largemouth bass stocked into Ohio River embayment areas.

\begin{tabular}{|c|c|c|c|c|}
\hline & \multicolumn{4}{|c|}{$\begin{array}{l}\text { Days post-tagging } \\
\text { (weighted average) }\end{array}$} \\
\hline & 6 & 19 & 66 & 429 \\
\hline Range of sample dates & 6 & $14-20$ & $102-144$ & $207-600$ \\
\hline Sample size & 80 & 50 & 13 & 14 \\
\hline \# with both tags intact & 73 & 45 & 11 & 5 \\
\hline \# with VIE mark only & 4 & 5 & 2 & 8 \\
\hline \# with anchor tag only & 3 & 0 & 0 & 1 \\
\hline Estimated VIE mark retention & 0.961 & 1.00 & 1.00 & 0.833 \\
\hline Variance of estimate & .000506 & 0 & 0 & .027778 \\
\hline Estimated anchor tag retention & 0.948 & 0.900 & 0.846 & 0.385 \\
\hline Variance of estimate & 0.000648 & 0.001837 & 0.010848 & 0.01972 \\
\hline
\end{tabular}


Figure 1. Visible implant elastomer marks were inserted into the soft interstitial space between anal fin rays.

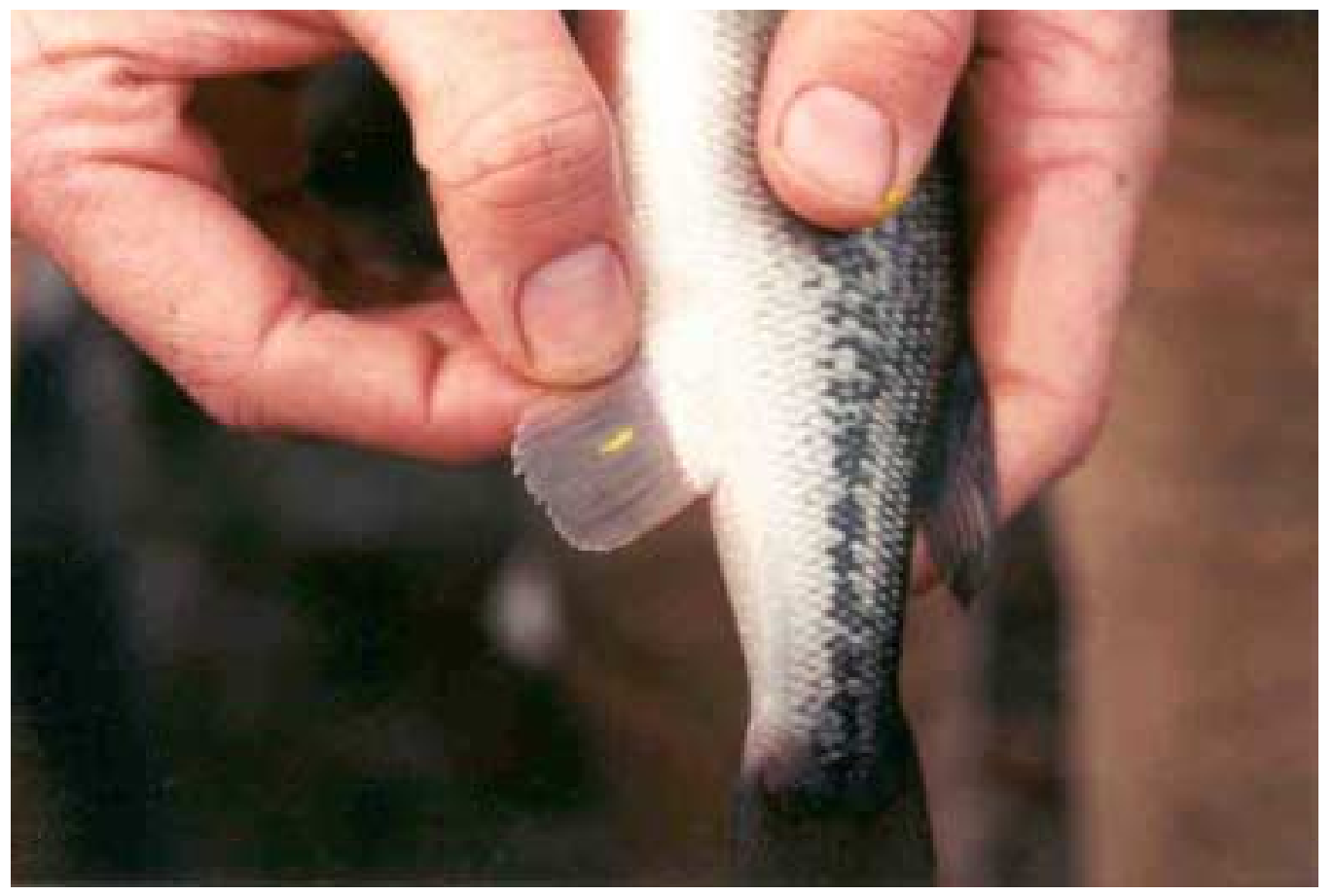




\title{
Chapter 3:
}

\section{Evaluation of a Fall Stocking of Intermediate and adult Largmouth Bass Into Two Ohio River Embayments}

\author{
Abstract \\ On October 20, 1998 the West Virginia Division of Natural Resources stocked adult, \\ mean total length $($ MTL $)=274$, and intermediate $(\mathrm{MTL}=179)$ size hatchery reared largemouth \\ bass into two embayment areas of the Ohio River to supplement existing populations. Stocked \\ fish were fitted with both an anchor tag and a visible implant elastomer mark to ensure \\ recognition. The objective of this study was to evaluate the effectiveness of this stocking event in \\ enhancing largemouth bass populations and improving angling opportunities. A multifaceted \\ sampling approach was incorporated to: (1) evaluate the persistence and return of stocked bass to \\ anglers' creel relative to that of wild largemouth bass; (2) estimate fidelity of stocked largemouth \\ bass to release sites; and (3) compare return rates and cost effectiveness of the two size classes. \\ Although stocked bass comprised the majority (81\%) of bass captured in electrofishing surveys \\ conducted during the first 30 days after stocking, percent composition declined to $50 \%$ in \\ January 1999, and continued to decline at an exponential rate throughout 1999 . Only two tagged \\ bass were reported during 1,085 hours of angling effort creeled in the two study pools. The \\ results of this study suggest that stocking advanced sized largemouth bass into Ohio River \\ embayments only provided a limited and short-term enhancement to the bass fishery in those \\ areas. Rapid loss of stocked fish in embayment areas was most likely due to post-handling and \\ natural mortality over the winter of 1999 combined with emigration of stocked fish out of the \\ stocked areas into the Ohio River main-stem.
}




\section{Introduction}

The Ohio River provides valuable angling opportunities along its border with West Virginia and constitutes almost half of the fishable water area in that state. A 1992-93 recreational use study conducted by the Ohio Department of Natural Resources revealed that black bass were the most sought after fish in the portion of the Ohio River bordering West Virginia (Schell et al. 1996). Over 391,700 angler-hours were spent fishing for black bass in this portion of the Ohio River in 1992 (Schell et al. 1996). Black bass (Micropterus spp.) fishing tournaments and tournament angling constitute a significant portion of the Ohio River fishery and provide substantial economic benefit to local communities. Given the popularity, size, and economic benefit of the Ohio River black bass fishery, agencies responsible for managing this resource are obligated to explore management techniques that may improve the quality of this popular fishery.

Largemouth bass (M. salmoides) are one of three black bass native to the Ohio River and West Virginia (Stauffer et al. 1995). Largemouth bass were relatively uncommon in the upper reaches of the Ohio River in comparison to northern spotted bass (M. punctulatis) and smallmouth bass (M. dolomieu) prior to 1933 (Trautman 1981). The construction of high lift dams during the 1950's greatly increased lentic habitat types favored by largemouth bass. This shift in habitat type may have led to the increase in largemouth bass that was observed throughout the Ohio River as well as other large river systems during fisheries investigations conducted after 1957 (Trautman 1981; Sheehan and Rasmussen 1999).

There has been a recent increase in public demand for management agencies to enhance largemouth bass populations in the Ohio River by means of supplemental stocking programs. After a 23-year record low catch rate was recorded during the 1997 black bass tournament 
season (Frank Jernejcic, West Virginia Division of Natural Resources, personal communication), Ohio River bass anglers expressed concern to the West Virginia Division of Natural Resources in regard to the quality and future of the black bass fishery. In 1997, Ohio River bass anglers founded an Ohio River chapter of the "Adopt-A-Bass" foundation, "out of concern and dissatisfaction by area fishermen of a deteriorating catch rate and loss of habitat on shorelines, embayments and tributaries of the Ohio River" (Adopt-A-Bass mission statement, 1997). One of the primary goals of the Adopt-A-Bass foundation has been to solicit legislative support for the implementation of a biannual largemouth bass stocking program on the Ohio River. Local anglers believe that a supplemental largemouth bass stocking program will enhance the river's largemouth bass population and improve angling opportunities on the Ohio River.

Largemouth bass are currently stocked by state management agencies in 41 states (Smith and Reeves 1986). Largemouth bass stocking programs are carried out to supplement existing populations, to introduce largemouth bass into new or reclaimed waters, correct prey/predator imbalances, or to satisfy anglers (Smith and Reeves 1986). Although stocking hatchery-reared largemouth bass is common practice for many state natural resource agencies, evaluations are often lacking (Murphy and Kelso 1986). The few evaluations of largemouth bass stocking programs that have been published indicate that return rates are usually low and results are mixed (Loska 1982; Boxrucker 1986; Ryan et al. 1996; Buynack et al. 1999; Buynak and Mitchell 1999). Largemouth bass stocking programs have mainly been carried out and studied in ponds and reservoirs (Loska 1982; Boxrucker 1986; Buynak and Mitchell 1999; Buynak et al. 1999). Little information exists on the feasibility of stocking largemouth bass into a large river system such as the Ohio River. 
Cost feasibility is a major concern of management agencies when determining whether or not to implement stocking programs. In a cost-benefit analysis of largemouth bass stocking Marzolf (1954) reported that return rates of stocked largemouth bass rarely exceeded 23\%, and that at a 20\% return rate the cost would equal $\$ 29.00$ per fish creeled (1954 costs). Buynak et al. (1999) found that the cost per harvested largemouth bass in a Kentucky impoundment ranged from $\$ 39$ to $\$ 66 /$ fish due to low return rates of hatchery-reared fish. High natural mortality rates may be a primary factor limiting return rates of stocked largemouth bass (Boxrucker 1986). Natural annual mortality rates of age- 1 and older fish have been shown to be as high as $75 \%$ in wild largemouth bass populations (Zweiacher and Brown 1971).

Research has indicated that stocking larger fish tends to produce better return rates than stocking fry or fingerling-sized largemouth bass (Loska 1982), but adult fish may not be the most cost efficient size to stock due to the high costs associated with rearing (Snow 1968). The development of artificial diets for largemouth bass culture in recent years has increased the availability and lowered costs associated with stocking larger size largemouth bass (Satterfield and Flickinger 1986).

Past studies have suggested that largemouth bass exhibit limited movements in ponds and small impoundments (Lewis and Flickinger 1967; Mesing and Wicker 1986). Copeland and Noble (1994) reported that the majority of tagged age-0 largemouth bass were most likely to be recaptured in the vicinity of their original capture site, indicating limited movement. Fidelity of hatchery-reared largemouth bass to release sites may prove to have important management implications for developing successful large river stocking programs. The Ohio River main-stem presents an obstacle to management agencies trying to implement largemouth bass stocking programs due to the high cost to produce the number of fish required to stock such a large area. 
If stocked largemouth bass show fidelity to release sites, it may prove feasible to improve largemouth bass catch rates in the Ohio River by stocking embayment and backwater habitat areas where angling efforts are concentrated during much of the year (Schell et al. 1996). Stocking embayment and backwater areas would be more economically feasible than trying to incorporate a stocking program to include the entire main-stem of the Ohio River.

In fall, 1998 the West Virginia Division of Natural Resources stocked adult and intermediate hatchery reared largemouth bass into two embayment areas of the Ohio River. The objective of this study was to evaluate the effectiveness of this stocking event as a management tool for enhancing Ohio River embayment largemouth bass populations. To do this we (1) evaluated persistence and return of stocked largemouth bass to anglers' creel relative to that of wild largemouth bass, (2) evaluated the fidelity of stocked largemouth bass to embayment release sites, and (3) compared return rates and cost effectiveness of two size classes of hatchery reared largemouth bass.

\section{Study Area}

The embayment areas used for stocking were determined in consultation with the West Virginia Division of Natural Resources based upon surface area, quality of largemouth bass habitat, and historical fishing pressure (Scott Morrison, West Virginia Division of Natural Resources, personal communication,). Little Mill Creek (9 hectares) is located in the Racine Pool (river kilometer, RK, 372.6), and French Creek (48 hectares) in the Willow Island Pool (RK 253.5)(Figure 1). Both embayment areas used for this study are characterized by shallow, turbid water with flooded timber and aquatic vegetation occurring in littoral areas. Substrate in these embayments is composed mostly of deposited silt and organic debris. The forage base for 
largemouth bass in Ohio River embayment areas primarily consists of gizzard shad (Dorosoma cepedianum), various sunfish (Lepomis spp.), and minnow species (Notropis spp.) (Hedrick 1995).

\section{Materials and Methods}

Little Mill Creek and French Creek were stocked on October 20, 1998 with hatchery reared, advanced size northern largemouth bass. Stocked fish were of two sizes: adults (mean total length, MTL, $=273 \mathrm{~mm})$ and intermediates $(\mathrm{MTL}=178 \mathrm{~mm})($ Table 1). A total of 2,641 intermediate and 1,009 adult size largemouth bass were stocked into French Creek, and 647 intermediates and 240 adults into Little Mill Creek. This corresponds to densities of approximately 55 intermediate and 21 adult/hectare in French creek and 72 intermediate and 27 adult/ hectare in Little Mill Creek (Table 2). The largemouth bass used for this study were purchased from a private aquaculture vendor (Sprock Fish Hatchery, Duncannon, PA). Stocked largemouth bass were reared on a pellet diet in hatchery ponds and purchased at a cost of $\$ 3.50$ and $\$ 5.00$ per fish for intermediate and adult fish, respectively. The adult size class used for stocking were spawned in May 1997, and the intermediate size in May 1998.

An essential aspect of this study was the ability to detect stocked, hatchery reared largemouth bass from the native largemouth bass populations in the study areas. Two separate tagging methods were employed on each fish prior to stocking to help ensure the detection of hatchery-reared fish. Prior to stocking, each largemouth bass was fitted with a Floy ${ }^{\circledR}$ FD-68B anchor tag bearing a unique, non-sequential identification number along with a contact name and telephone number. The unique, non-sequential identification numbers located on each tag helped ensure that anglers were unable to provide false capture information. 
The anchor tags were inserted at the base of the dorsal fin at a $45^{\circ}$ angle, so the anchor end of the tag locked behind the pterygiophores (Tranquilli and Childers 1982). Tranquilli and Childers (1982) reported that growth and survival of largemouth bass tagged in this fashion were not significantly different than those of untagged largemouth bass. Tag loss among largemouth bass tagged in this fashion has been reported to be substantial over a three month time period (Wilbur \& Duchrow 1973). Due to the length of the project, the loss of anchor tags over time could conceivably lead to the underestimation of stocked largemouth bass catch rates and contribution to the fishery. To minimize this possibility, each largemouth bass was also tagged using a second method of marking. A visible implant fluorescent elastomer (VIE) mark (Northwest Marine Technology, Inc. ${ }^{\circledR}$ ), was injected into the anal fin of each fish in order to ensure the ability of project personnel to identify hatchery reared largemouth bass in the event the anchor tag was shed or lost during the course of the study. After reviewing past VIE retention studies (Bailey et at. 1998, Haines et at. 1998, Hale and Grey 1998) and experimenting with various tagging locations, the interstitial space between anal fin rays was chosen for the VIE mark. This area was chosen based upon the ease of tagging and the high visibility of the mark in this location. Separate elastomer colors were assigned to the different size class and study site batches. Short-term (31 days) tag retention of both marking methods in these stocked bass was observed to be $>95 \%$ in hatchery ponds (Chapter 2 ).

Hatchery largemouth bass were hauled and handled according to methods described by Carmichael et al. (1984), in an attempt to minimize handling stress and mortality. Prior to being tagged, hatchery largemouth bass were anesthetized with a clove oil solution $(1.2 \mathrm{ml}$ per $20 \mathrm{~L}$ of $\mathrm{H}_{2} \mathrm{O}$ ) as described by Peake (1998) to minimize handling stress. Weight (nearest gram), total length (nearest millimeter), and unique identification tag numbers were recorded for each 
hatchery fish after the tagging process was completed. Total lengths were shown to be significantly $(\mathrm{p}<0.05)$ different between the two size classes used for stocking (Table 1). Despite attempting to minimize post-handling mortality, $26.5 \%$ and $42.9 \%$ delayed mortality was observed in intermediate and adult size largemouth bass respectively, held in hatchery ponds for a 31day period (Chapter 2).

Fisheries personnel from the West Virginia Division of Natural Resources and West Virginia University conducted tagging procedures at Palestine State Fish Hatchery, West Virginia. After tagging was completed, the fish were hauled from Palestine Fish Hatchery to the study areas via West Virginia Division of Natural Resources stock trucks. The largemouth bass were unloaded from the hatchery trucks at the study site and loaded into WVNDR stocking boats. They were then transported by boat to the middle of their respective embayment areas and released. Visual observations were conducted at each study site for two days following the stocking to monitor for signs of immediate post-stocking mortality. No indication of immediate post-stocking mortality was observed.

A multifaceted sampling approach was adopted to monitor the persistence, movement, and relative return rates of stocked largemouth bass. Electrofishing surveys, creel surveys, black bass tournament catch data, and angler call-in information were used to accomplish the objectives of the study. Shoreline electrofishing surveys were regularly conducted (monthly excluding January and February) in the study area to determine what portion of the largemouth bass population within the study embayments was of hatchery origin. Electrofishing has been shown to be a good relative indicator of largemouth bass densities (Hall 1986; Buynak and Mitchell 1993). Boat electrofishing surveys were conducted using a standardized unit of time (15 minutes per unit) with replication ( $\mathrm{N}=4$ units per survey) in the study embayments. Surveys 
were also periodically conducted (two occasions in each study pool) along main-stem shorelines and other embayment areas located in close proximity (within $4 \mathrm{~km}$ ) to the stocked embayments. This was done in an attempt to document instances of dispersal by hatchery largemouth bass subsequent to stocking. The boat used to conduct electrofishing surveys was equipped with a single sphere type electrode and fitted with a VVP-15 Coffelt $^{\circledR}$ unit operated at 280-500 V DC, 2-6 A, 25\% duty cycle, and 40-120 pulses/sec (Hall 1986). An effort was made to conduct electrofishing surveys at each study site on at least a monthly basis during the field season (March-October). Shoreline electrofishing surveys were conducted with one person selectively dipnetting all blackbass while another person operated the boat. Selective dipnetting was used to maximize electrofishing effort for the targeted species (Twedt et al. 1992). Electrofishing efforts were concentrated near structurally complex habitats such as flooded timber, aquatic vegetation, and brush piles to maximize electrofishing efficiency (Killgore et al. 1989). A stopwatch was used to monitor active electrofishing time. Largemouth bass captured during surveys were weighed, measured and the presence of a Floy ${ }^{\circledR}$ tag or VIE mark was noted. Largemouth bass lacking either a Floy ${ }^{\circledR}$ tag or VIE mark were assumed to be of wild origin.

Most methods of estimating survival using mark and recapture techniques as well as catch-effort methods require the population in question remain closed to emigration and immigration (Krebs 1999). The embayment areas used for stocking remain connected to the Ohio River main-stem throughout the year, therefore violating the "closed system" assumption. Other mark-recapture survival models, such as the Jolly-Seber method, have been developed to estimate survival in open populations (Krebs 1999). These methods incorporate multiple catch history of marked animals in an attempt to estimate survival. Unfortunately, only four tagged 
bass were recaptured on more than one occasion over the course of this study. This lack of recapture history severely limited the power of tests such as the Jolly-Seber.

Changes in the ratio of stocked to wild (stocked/wild ratio) largemouth bass captured during surveys were used to assess the relative persistence of hatchery reared fish in the stocked embayment areas. Changes in the stocked bass/wild ratio were used because of disparities (environmental and biological) in electrofishing efficiency over the course of the study that prevented direct comparison of catch per unit effort (CPUE) over time (Sammons and Bettoli 1999; Reynolds 1996). Seasonal changes of environmental factors such as conductivity and water temperature (Hill and Willis 1994; Reynolds 1996), as well as seasonal movements and habitat selection (Raibley et al. 1997) of largemouth bass can affect electrofishing efficiency and can bias catch per unit effort data. If the assumption can be made that catch efficiency of stocked fish is comparable to that of the wild bass population, then analyzing changes in the stocked/wild ratio over time may provide a more accurate indication of the relative presence of hatchery reared bass in the stocked embayments.

A Chi-square test was used to determine if the adult size class used for stocking exhibited significantly higher return rates than the intermediate size class based on the ratio stocked. An estimate of relative survival (RS) of intermediate versus adult size classes was then calculated by comparing ratios of the number of bass stocked to the number recaptured during electrofishing surveys and angler call-in reports (Heidinger and Brooks 1998) as follows:

$$
\mathrm{RS}=\left(\mathrm{n}_{\mathrm{a}} / \mathrm{N}_{\mathrm{a}}\right) /\left(\mathrm{n}_{\mathrm{i}} / \mathrm{N}_{\mathrm{i}}\right)
$$

$\mathrm{n}_{\mathrm{a}}=$ the number of largemouth bass from the adult size class that were later recaptured (through electrofishing surveys or angler call-in reports); $\mathrm{N}_{\mathrm{a}}=$ the number from that size class stocked; $\mathrm{n}_{\mathrm{i}}$ $=$ the number of bass from the intermediate size class recaptured; and $\mathrm{N}_{\mathrm{i}}=$ the number from that 
size class stocked. It was assumed that electrofishing vulnerability and reporting rates were consistent between the two size classes.

Creel surveys were conducted at the study sites as well as at popular access landings in the Willow Island and Racine pools. Due to limited resources, the large size of the study area (embayments, tributaries, and main-stem habitat), and the large number of access sites, the creel was not designed to estimate total angling effort. Sampling dates and times of creel surveys were not chosen randomly, but instead to maximize angler interview potential. The objective of the creel survey was to estimate what portion of largemouth bass captured in the embayments and throughout the study pools were of hatchery origin at a given point in time. Creel surveys were conducted at the mouth of the stocked embayments. A creel clerk was positioned at the mouth of the embayment and anglers were interviewed as they left the embayment area or completed their trip. Interviewed anglers were asked a series of questions including: (1) targeted species, (2) the number of non-tagged largemouth bass captured, (3) the number of tagged largemouth bass, (4) time spent angling in the embayment, and (5) number of tagged (stocked) and wild bass harvested. These data were used to compare catch rates of stocked and wild bass over time in an attempt to estimate the relative contribution of stocked bass to anglers' creel. A total of 21 on site creel surveys were conducted within the first year after stocking. An attempt was made to conduct creel surveys (average duration of creel $=7$ hours) at the stocked embayments at least monthly during the first six months of the study.

Access point creel surveys were also conducted by waiting at popular public access landings in the Racine and Willow Island Pool where anglers were interviewed as they returned from completed trips. Access point creel surveys were initiated in June, 1999 to monitor relative catch rates of stocked bass outside of the stocked areas after call-in tag reports indicated that a 
number of bass had dispersed out of the embayment areas subsequent to stocking. These surveys also provided a much higher number of angler interviews in a given period of time than surveys conducted at the study sites. Access point surveys were conducted a total of 26 times over the course of the project (October 1998 - June 2000.)

Signs were posted at access landings, bait stores, and marinas in the vicinity of the study areas with the purpose of informing anglers about the project and encouraging them to report any tagged bass that they may catch. Also, information concerning the project was distributed at local bass club meetings and at bass fishing tournaments encouraging anglers to report the catch of any tagged fish. No reward was offered to anglers returning tagged bass information. Anglers reporting the capture of a tagged bass were asked the date and location of capture, tag number, and size of the fish. These data were used as a relative indicator of the fidelity shown by stocked bass to their release sites. It was also used to compare return rates of the adult versus intermediate size classes.

A number of black bass tournaments held in the Willow Island and Racine pools during 1999 and 2000 were attended to determine what portion of the tournament catch in those areas consisted of stocked bass. Tournament participants were interviewed at the conclusion (weighin) of each tournament to determine if tagged bass were captured during their trip. Anglers participating in these tournaments were not restricted to the pool in which the tournament was held, making it impossible to discern what portion of the angling effort occurred in the vicinity of the study areas. Therefore, CPUE (number of stocked fish/hour of angling effort) estimates of stocked bass caught during tournaments are conservative estimates of catches in stocked embayments due to tournament angling occurring outside the area of study. However, tournament CPUE does provide a good measure of contribution of stocked fish to this segment 
of the recreational fishery following movements and mortality of stocked fish. Out of concern for high loss rates of anchor tags, all largemouth bass weighed-in during 2000 black bass tournaments were checked for the presence of a VIE mark by project personnel. Total angler hours and tournament catch data were obtained from West Virginia Division of Natural Resources tournament summaries (Frank Jernejcic, West Virginia Division of Natural Resources, personal communication). These data were used to calculate catch per effort of wild and stocked largemouth bass during black bass tournaments.

\section{Results}

\section{Electrofishing Data}

Electrofishing surveys revealed that the majority of largemouth bass initially captured in both study areas after stocking of French and Little Mill Creek were of hatchery origin (Figure 3). Stocked largemouth bass comprised $81 \%$ of all largemouth bass captured during electrofishing surveys conducted during the first 30 days after stocking ( $\mathrm{N}=138$ captured during this time). In French Creek, stocked bass accounted for $84 \%(\mathrm{~N}=123)$ of bass captured during the first 30 days. Although Little Mill Creek was stocked at higher densities of both adult and intermediate fish than French Creek (Table 2), recapture rates of marked fish during electrofishing surveys were lower in Little Mill Creek.

Although largemouth bass captured during fall 1998 and winter 1999 electrofishing surveys were predominantly of hatchery origin, catch per unit effort (CPUE) as well as percent composition of stocked largemouth bass in the study embayment areas declined rapidly over time. Percent composition of stocked bass captured during electrofishing surveys conducted in January 1999 declined to $50 \%$ (Figure 3) and continued to decline at an exponential rate 
throughout 1999 surveys. Catch rates of wild largemouth bass were also generally low and showed a high degree of variability between sample dates, but did not indicate a declining trend over time as did those of stocked fish (Figure 4). Stocked largemouth bass comprised only 15\% of the total bass sampled during spring, 1999.

To illustrate the rapid decline in stocked fish relative abundance, CPUE (number of bass/hour) of stocked largemouth bass, as well as the stocked/wild ratio were regressed using days post-stocking as the independent variable. These data were then fit to an exponential decay model in an attempt to obtain a relative estimation of hatchery-reared largemouth bass persistence in the stocked embayments (Figures 5). Using this negative decay regression model, we estimated that stocked bass did not contribute to the overall largemouth bass population in the French Creek embayment beyond 200 days subsequent to stocking (Figure 5). No largemouth bass exhibiting either an anchor tag, or VIE mark was captured during electrofishing surveys conducted in the stocked embayment areas beyond one year post-stocking $(N=60)$.

Although bass catches in the stocked embayments declined, few stocked bass were caught in electrofishing surveys outside of the stocking points in shoreline sampling of the Ohio River main-stem and nearby $(<5 \mathrm{~km})$ unstocked embayments. Stocked fish comprised only $2.2 \%$ (of $\mathrm{N}=135$ ) of the largemouth bass captured during these surveys. All three tagged largemouth bass captured in areas outside the stocking locations were caught in other embayment areas located in proximity to the stocked embayments during spring, 1999 surveys. No tagged bass were captured in Ohio River main-stem areas at any time during the study ( $N=19$ largemouth bass captured).

Electrofishing surveys indicate that largemouth bass stocked as adults were captured at a significantly $(\mathrm{p}<0.0005)$ higher rate relative to the intermediate size class (Table 3$)$. Relative 
survival of the adult size class was estimated to be 2.9 times higher than that of the intermediate class based on these data (Table 4). The purchase cost of adult largemouth bass was 1.43 times higher than the intermediate size-class. Based on electrofising return information, the relative cost per return of the adult size class is estimated to be around twice that of intermediate size stocked largemouth bass electrofishing returns.

\section{Angler survey data}

Creel surveys indicated relatively low catch rates of both wild and stocked largemouth bass. A total of 91 anglers were interviewed during creel surveys conducted at the French Creek and Little Mill Creek study sites during 1998-99. Only 18 wild largemouth bass were reported during 208 hours of angling effort in the stocked embayments (CPUE $=0.09 \mathrm{fish} / \mathrm{hr}$.). Stocked largemouth bass constituted the majority (70\%) of bass caught in the study embayments during the first two months following stocking (Nov. - Dec. 1998). However, similar to electrofishing results, contributions of stocked bass to the creel declined rapidly with time. No tagged bass were reported after March 1999 (Figure 6). Catch rates of wild largemouth bass fluctuated greatly between surveys, but a declining trend could not be detected.

Despite interviewing hundreds of anglers at access areas, stocked largemouth bass appear to have contributed little to angler catch rates in either study pool. A total of 203 angler interviews corresponding to 1,085 hours of angling effort were recorded during surveys conducted at public access landings in the Racine and Willow Island Pools. Only two tagged largemouth bass were reported captured during public access creel surveys. This amounted to $0.044 \%$ of total largemouth bass catch reported during these surveys $(\mathrm{N}=453$ largemouth bass caught during these surveys). 
Creel surveys suggested that direct harvest mortality of both stocked and wild largemouth bass were minimal. Only one wild largemouth bass was reported as harvested during either an on-stite or access point creel surveys $(\mathrm{N}=501$ bass reported caught). No tagged largemouth bass were reported harvested during either type of creel survey.

\section{Black Bass Tournament Data}

A total of 26 black bass tournaments held in the Racine and Willow Island Pools were attended during 1999 and 2000 to assess stocked fish contribution to these anglers, again with low returns of stocked fish. Data gathered from these tournaments indicate that stocked largemouth bass comprised a minute portion of the tournament largemouth bass catch in these areas (Table 5). Attended tournaments were held at popular access landings in the Willow Island and Racine Pools. Black bass tournaments held in the Racine and Willow Island pools were attended on 16 occasions during 1999. These tournaments enforce a 304mm minimum size limit. No stocked largemouth bass were weighed-in during attended tournaments in 1999. A total of 94 largemouth bass were $>304 \mathrm{~mm}$ when stocked, and a number of others should have recruited into the tournament fishery sometime during the 1999 season (Figure 7). However, 15 tagged bass $<304 \mathrm{~mm}$ were reported (caught and released) by tournament anglers. This corresponds to one tagged fish of any size being captured for every 633 hours of tournament angling effort (Table 5). In comparison, it took anglers an average of 25 hours to catch one tournament size (> $304 \mathrm{~mm}$ ) wild largemouth bass during attended 1999 tournaments.

Black bass tournaments were attended on 10 occasions during 2000. After having one complete growing season since being stocked, a large portion of the hatchery-reared fish should have attained the minimum tournament size by 2000. Tagged fish only contributed slightly to 
the tournament catch during the 2000 tournament season. Anglers weighed in 7 (1.4\% of total LMB catch) tagged largemouth bass during attended tournaments. This corresponds to 1 tagged largemouth bass captured for every 876 hours of tournament angling effort. Only one of the tagged fish returned during a tournament even bore remnants of an intact anchor tag. The other six were identified as of stocked origin by the presence of a VIE tag. This suggests that tag loss

of the Floy ${ }^{\circledR}$ anchor tags was substantial by the second year of the project. No tagged bass $<304$ mm were reported by anglers, but this may reflect the anglers inability to detect VIE tags in the absence of a floy tag. Of the seven stocked fish returned at 2000 tournaments, 6 were stocked at the intermediate size class and 1 as an adult, suggesting most surviving hatchery-reared fish had achieved the minimum tournament size by 2000 .

\section{Angler call-in data}

Angler call-in reports of tagged fish and catch location data obtained from tournament anglers suggest a high degree of dispersal of hatchery bass following stocking. Only $22 \%$ $(\mathrm{N}=59)$ of the tagged largemouth bass reported by anglers were caught in either French or Little Mill Creek (Figure 8). The majority (66\%) of fish reported were captured $>1 \mathrm{~km}$ from the stocked embayment areas. Approximately $7 \%$ of the reported capture locations were $10 \mathrm{~km}$ or further from the stock sites. The majority of reported bass were captured in embayment habitat types (83\%), as opposed to Ohio River mainstem shoreline areas (7\%), and Ohio River tributaries (10\%). The bulk of call-in capture reports of tagged bass occurred during 1998 (67\%). No tagged largemouth bass were reported via telephone after May 1999. Similar to electrofishing survey results, largemouth bass stocked at the adult size class were reported at a significantly $(\mathrm{p}<0.05)$ higher rate than expected based upon the ratio of adult/intermediate used 
for stocking (Table 6). With these angler call-in data relative survival of the adult size class was estimated to be 2.1 times higher than that of the intermediate class (Table 4). Based upon angler call-in reports, the relative cost effectiveness of the adult size class is estimated to be around 1.5 times better than that of intermediate size stocked largemouth bass.

\section{Discussion}

Dispite stocking over 3,500 largemouth bass at densities of $>55$ intermediate and $>21$ adult fish per hectare of embayment area, the fall stocking of largemouth bass into Ohio River embayment areas was not found to be an efficient way of enhancing largemouth bass populations. Contributions of stocked fish to anglers' creel and in electrofishing surveys declined rapidly after stocking. Although most largemouth bass caught in surveys immediately after stocking were of hatchery origin, contributions diminished precipitously with time. Contributions of stocked largemouth bass declined from $81 \%$ immediately after stocking to only $15 \%$ during electrofishing surveys conducted spring, 1999. Also, low catch rates of stocked bass reported during creel surveys and the paucity of tagged fish captured during black bass tournaments provide additional evidence that stocked fish did not make a substantial contribution to the fishery after fall, 1998. These data suggest that fall stocking of largemouth bass Ohio River embayments in this manner provided a limited, short-term benefit to the fishery. Our findings are similar to other largemouth bass stocking evaluations conducted in lakes and small impoundments (Loska 1982; Boxrucker 1986; Ryan et al. 1996; Buynack and Mitchell 1999; Buynack et al. 1999) that have reported low return rates of stocked fish.

Because fish were only stocked on one occasion it is natural to expect that their abundance and contribution to the fishery should diminish over time, but the rapidness in which 
returns decreased indicate that this method of stocking was a relatively ineffective means of enhancing embayment largemouth bass populations. A number of reasons may explain why stocked bass did not contribute substantially to the recreational catch or to sampling gear. These include: (1) high mortality during the first six months at liberty, (2) emigration of hatcheryreared fish out of stocked embayments, (3) immigration of wild largemouth bass into stocked embayments, or (4) high tag loss making them impossible to discern from wild largemouth bass.

Although no signs of immediate mortality due to hauling and handling procedures were observed, post-stocking mortality was quantified for 31 days and found to be substantial (Chapter 2). Although Tranquilli and Childers (1982) reported no significant effect of anchor tags on the survival and growth of largemouth bass, the combined effects of handling stress and long hauling distance were thought to have a negative impact on post-stocking survival rates in this study (Chapter 2). Reported stocking rates were adjusted to account for this delayed mortality (Table 2). Data collected from largemouth bass held in hatchery ponds for one month after tagging suggest that largemouth bass in the intermediate size range were better able to withstand the stresses associated with this type of tagging/hauling better than the adult size class (Chapter 2).

Extremely low post-stocking survival rates have been observed in pellet-reared muskellunge (Esox masquinongy) compared to those raised on a minnow diet (Larscheid et al. 1999). The low survival rates associated with pellet-reared fish in that study were contributed to poor health. The majority of tagged largemouth bass recaptured the first month following stocking exhibited high levels of fungal infection. Deformities in the lower jaw were also prevalent in recaptured, tagged bass. Nutritional problems (vitamin C deficiency), including deformities of the lower jaw, have been evident with pellet-reared largemouth bass (Wes Porak, 
Florida Fish and Wildlife Conservation Commission, personal communication) as well as other hatchery-reared species (Colesante and Bubnack 1993; Jorgensen 1994). The combination of post-handling mortality and poor health (jaw deformities) of stocked largemouth bass may have led to heightened mortality rates over the winter of 1998-99.

Seasonal immigration of wild largemouth bass into stocked embayment areas could have conceivably contributed to the observed decline in percent composition of stocked fish. Research has indicated that largemouth bass immigrate into embayment areas of large river systems in winter months and during periods of high flow (Raibley et al. 1997). This behavior may have contributed to the decline in percent composition of stocked fish by increasing wild largemouth bass populations in the stocked embayments.

Outmigration of tagged bass after stocking may explain declining capture rates as well. As stocked bass dispersed out of the embayment areas and dissipated into the Ohio River mainstem (as angler call-in data suggest) the likelihood of their recapture became remote due to a diluting effect created by the large area of water in the Ohio River main-stem. Post-stocking fish dispersal is influenced by a multitude of factors including habitat diversity and availability, as well as abundance and species composition of resident fish fauna (Murphy and Kelso 1986). Also, home range sizes of largemouth bass have been shown to increase when forage abundance is low (Savitz et al. 1983). It is likely that the high rate of dispersal suggested by angler call-in reports was related to overcrowded conditions and low forage densities in the stocked embayements. Although an attempt was made to sample main-stem shoreline habitat areas, very few largemouth bass were captured during electrofishing surveys conducted in these areas. The small sample size of largemouth bass taken in the main-stem may be a reflection of gear limitation. The electrofishing boat used for this project was designed to sample shallow littoral 
areas typically found in embayment habitats and may not have performed as well in the mainstem shoreline areas due to the proximity of deeper water where fish could avoid the gear. High dispersal rates suggested from angler call-in data suggest that the densities used for stocking may have exceeded the carrying capacity of available forage and/or habitat in the stocked embayments.

The fact that Little Mill Creek exhibited lower return rates of hatchery reared bass than French Creek despite higher initial stocking densities suggests that stocking rates may influence natural mortality rates by causing a shift from density-independent to density-dependent control factors (Snow 1978), thus undermining enhancement efforts. Terre et al. (1993) found that supplemental stocking success was inversely related to recruitment levels of the wild bass populations, suggesting that competition for limited resources may exist between stocked and wild largemouth bass. In this study, high densities of largemouth bass may have increased mortality or emigration due to density-dependent processes.

Starvation and poor growth of stocked piscivores can occur if stocking events are not synchronized with an available supply of forage fish (Ney and Orth 1986). Largemouth bass have been shown to rely almost exclusively on gizzard shad in the Ohio River during fall months (Hedrick 1995), but only young age groups of shad are vulnerable to largemouth predation (Storck 1986). Buynak et al. (1999) used ratios of available prey (AP) to available predators (P) to match the size of stocked largemouth bass with prey availability in a small Kentucky impoundment and found that stocked bass needed to be at least $203 \mathrm{~mm}$ or larger to have sufficient prey biomass.

Mortality due to harvest did not appear to be a major factor contributing to declining return rates of stocked bass. No tagged largemouth bass were harvested during creel surveys or 
at black bass tournaments over the course of this project. The lack of largemouth bass harvest by anglers may be a result of negative perceptions associated with consumption advisories placed on various Ohio River fish species or a conservation ethic among bass anglers. Mortality as a result of catch and release angling was suggested as a possible factor influencing survival of subadult largemouth bass stocked into a Kentucky impoundment (Buynak et al. 1999). However, our stocking took place toward the end of fall when water temperatures are cool and angling pressure has begun to taper off. Fishing pressure for largemouth bass on the Ohio River is lowest during the winter months (Schell 1993). The percent composition of stocked bass observed during electrofishing surveys had declined dramatically before fishing pressure resumed in the spring of 1999 (Figure 3). Thus, neither direct nor indirect angling mortality appear to be likely causes for the rapid decline in stocked bass observed in electrofishing surveys and anglers' creel.

The recruitment of a new wild largemouth bass year-class into the embayment bass populations was not likely a factor in reducing the percent composition of stocked fish in electrofishing surveys. Young-of-year wild largemouth bass from the 1998-year class did not become susceptible to electrofishing gear until October 1999. The rapid decrease in percent composition of stocked bass had already occurred before these age-0 fish reached a susceptible size.

The loss of tags is also an unlikely explanation for the precipitous decrease in occurrences of stocked bass. Rapid declines in percent composition of stocked fish were observed in electrofishing surveys conducted the first 200 days after stocking. Short-term (30 days) tag retention was shown to be $>95 \%$ for both methods of marking in largemouth bass held in hatchery ponds (Chapter 2). Wilbur and Duchrow (1982) reported tag loss estimates of only 
$12 \%$ over a three-month period in largemouth bass tagged with FD-68B floy tags. The probability that stocked fish recaptured between 207-600 days at liberty shed both identification marks (Floy ${ }^{\circledR}$ and VIE) was estimated to be around 10 percent (Chapter 2). These data suggest that stocked largemouth bass would have most likely retained one of the two tagging methods throughout the first 200 days at liberty. Thus, it seems the decline in numbers of stocked bass was an actual decline in density and not due to tag loss. Also, to minimize the chance of falsely identifying a stocked largemouth bass as of wild origin due to loss of anchor tags, fish captured in electrofishing surveys and during 2000 black bass tournaments were checked by project personnel for the presence of either tag type. Of the seven stocked fish returned during 2000 black bass tournaments, only one was identified by the presence of an anchor tag. The other six were identified by VIE marks. These data indicate that anchor tag loss may have possibly led to underestimation of stocked bass catch rates reported during 2000 creel surveys due to the inability of fisherman to identify stocked fish based on VIE tags alone.

The results of this study suggest that stocking advanced sized largemouth bass into embayment areas during fall 1998 provided only short-term enhancement to the bass fishery in those areas. Rapid loss of stocked fish in embayment bass populations was most likely due to high natural and delayed post-handling mortality over the winter of 1999 combined with emigration of stocked fish into Ohio River main-stem areas. The lack of fidelity shown by stocked largemouth bass to release sites, despite stocking during the fall of year when forage is most available, indicates that Ohio River embayment habitat areas cannot be thought of as discrete areas in terms of stocking. Largemouth bass stocked at the adult size class returned at significantly higher rates than the intermediate sized fish in both creel and electrofishing surveys, even though adult sizes were shown to incur significantly higher delayed post-handling mortality 
(Chapter 2). Return data from electrofishing surveys as well as tag returns from angler call-ins indicate that the adult size class was more cost efficient than the intermediate size class even though the former were purchased at a higher price, but it is interesting to note that six of the seven marked fish that were captured during 2000 bass tournaments were stocked at the intermediate size class. Although the sample size is small, this suggests that long-term survival of the intermediate size class may actually be higher than the adult size class but further investigation is needed to determine optimum stocking sizes. It was assumed that electrofishing vulnerability and reporting rates were consistent between the two size classes when comparing return rates of the two size classes. This is likely a valid assumption due to the close proximity in range of the two size classes, but it is conceivable that reporting rates and capture vulnerability may have been higher for the adult size class.

The decision to implement a supplemental largemouth bass stocking program in Ohio River embayment areas should be based on evaluations to determine if these habitats can support cultured bass and if stocking will achieve positive management objectives set in advance (AFS Symposium 1995). Although the results of this pilot study indicated that stocked fish only provided short-term enhancement to the bass populations in the study areas, it does not suggest that the use of cultured largemouth bass is not a viable management option. Further scientific evaluations are needed to determine the biological feasibility of a largemouth bass stocking program. The dynamics governing large river largemouth bass populations are poorly understood (Sheehan and Rasmussen 1999), and before any large scale stocking program is implemented, a better understanding of the status and trends exhibited by the Ohio River wild largemouth bass population is needed (AFS Symposium 1995). In addition, habitat needs as well as prey availability require further study to determine optimum stocking times, locations, and 
densities. The possibility of deleterious effects of genetic outbreeding depression on wild bass populations due to stock transfer should also be addressed before a large-scale stocking program is implemented (Philipp and Claussen 1995). Last but not least, the need for habitat restoration should not be ignored. Improvements in water quality as well as habitat restoration are the best way to sustain native largemouth bass populations and maximize enhancement efforts through the use of cultured fish. The use of cultured largemouth bass, as a method of enhancing Ohio River fishing opportunities, will prove to be beneficial only if management agencies are allowed to incorporate it as part of a sound restoration program or the sound management of the Ohio River aquatic ecosystem. 


\section{References}

American Fisheries Society Symposium. Pages 585-586 in R. H. Stroud, editor. Fish culture in fisheries management. American Fisheries Society, Fish Culture Section and Fisheries Management Section, Bethesda, Maryland.

Bailey, R. E., J. R. Irvine, F. C. Dalziel, and T. C. Nelson. 1998. Evaluations of visible Implant Fluorescent Tags for Marking Coho Salmon Smolts. North American Journal of Fisheries Management 18:191-196.

Boxrucker, J. 1986. Evaluation of Supplemental Stocking of Largemouth Bass as a Management Tool in Small Impoundments. North American Journal of Fisheries Management 6:391-396.

Buynak, G. L., and B. Mitchell. 1993. Electrofishing Catch per Effort as a Predictor of Largemouth Bass Abundance and Angler Catch in Taylorsville Lake, Kentucky. North American Journal of Fisheries Management 13:630-633.

Buynak, G. L., and B. Mitchell. 1999. Contribution of Stocked Advanced-fingerling Largemouth Bass to the Population and Fishery at Taylorsville Lake, Kentucky. North American Journal of Fisheries Management 19:494-503

Buynak, G. L., B. Mitchell, D. Michaelson, and K. Frey. 1999. Stocking Subadult Largemouth Bass to Meet Angler Expectations at Carr Creek Lake, Kentucky. North American Journal of Fisheries Management 19:1017-1027.

Carmichael, G. J., J. R. Tomasso, B. A. Simco, and K. B. Davis. 1984. Characterization and Alleviation of Stress Associated with Hauling Largemouth Bass. Transactions of the American Fisheries Society. 113:778-785. 
Colesante, R. T., and J. Bubnack. 1993. Deformitities in Chautauqua muskellunge reared on artificial diets. Proceedings of the Coolwater Fish Culture Workshop, Spirit Lake, Iowa.

Copeland, J. R., and R. L. Noble. 1994. Movements by Young-of-Year and Yearling Largemouth Bass and Their Implications for Supplemental Stocking. North American Journal of Fisheries Management 14:119-124.

Haines, G. B., S. H. Severson, and T. Modde. 1998. Evaluation of Razorback Sucker and Colorado Squawfish Batch Marking Techniques. The Progressive Fish Culturist 60:272275.

Hale, R. S., and J. H. Gray. 1998. Retention and Detection of Coded Wire Tags and Elastomer Tags in Trout. North American Journal of Fisheries Management 18:197-201.

Hall, T. J. 1986. Electrofishing Catch per Hour as an Indicator of Largemouth Bass Density in Ohio Impoundments. North American Journal of Fisheries Management 6:397-400.

Hedrick, J. D. 1995. A Bioenergetics Evaluation of Growth and diet of Three Sport Fishes in the Ohio River, West Virginia. Masters Thesis. West Virginia University, Morgantown, West Virginia.

Heidinger, R. C., and R. C. Brooks. 1998. Relative Survival and Contribution of Saugers Stocked in the Peoria Pool of the Illinois River, 1990-1995. North American Journal of Fisheries Management 18:374-382

Hill, T. D., and D. W. Willis. 1994. Influence of water conductivity on Pulsed AC and Pulsed DC Electrofishing Catch Rates for Largemouth Bass. North American Journal of Fisheries Management 14:202-207. 
Jorgensen, W. D. 1994. Spirit Lake Hatchery production report. Iowa Department of Natural Resources, Fish Culture Section, Completion Report, Des Moines.

Killgore, J. K., R. P. Morgan II, and N. B. Rybicki. 1989. Distribution and Abundance of Fishes Associated with Submersed Aquatic Plants in the Potomac River. North American

Journal of Fisheries Management 9:101-111.Krebs, C.J. 1999. Ecological Methodology. $2^{\text {nd }}$ Edition. Publisher: Jim Green.

Krebs, C. J. 1999. Ecological Methodology $-2^{\text {nd }}$ Edition. Addison-Wesley Educational Publishers, Inc.

Larscheid, J., J. Christianson., T. Gengerke, and W. Jorgensen. 1999. Survival, Growth, and Abundance of Pellet-Reared and Minnow-Reared Muskellunge Stocked in Northwestern Iowa. North American Journal of Fisheries Management 19:230-237.

Lewis W. M., and S. A. Flickinger. 1967. Home Range Tendency of the Largemouth Bass (Micropterus Salmoides). Ecology, Vol. 48, No. 6.

Loska, P. M. 1982. A Literature Review on the Stocking of Black Basses (Micropterus spp.) in Reservoirs and Streams. Georgia Department of Natural Resources, Game and Fish Division. Study SW-1 Atlanta, Georgia.

Marzolf, R. C. 1954. Practicality and economic feasibility of rearing and stocking largemouth bass on one pound size. Mo. Cons. Comm. Fed. Aid Proj. F-1-R-3. Work Plan 4, Job 1. 21 pp.

Mesing, C. L., and A. M. Wicker. 1986. Home range spawning migrations, and homing of radio-tagged Florida largemouth bass in two central Florida lakes. Transactions of the American Fisheries Society 115:286-295. 
Murphy B. R., and W. E. Kelso. 1986. Strategies for evaluating fresh-water stocking programs: past practices and future needs. Pages 306-313 in Stroud (1986).

Ney, J. J., and D. J. Orth. 1986. Coping With Future Shock: Matching Predator Stocking Programs To Prey Abundance. Pages 81-92 in R. H. Stroud, editor. Fish culture in fisheries management. American Fisheries Society, Fish Culture Section and Fisheries Management Section, Bethesda, Maryland.

Peake, S. 1998. Sodium Bicarbonate and Clove Oil as Potential Anesthetics for Nonsalmonid Fishes. North American Journal of Fisheries Management 18:919-924.

Phillipp, D. P., and J. E. Claussen. 1995. Fitness and Performance Differences between Two Stocks of Largemouth Bass from Different River Drainages within Illinois. Pages 236-243 in R. H. Stroud, editor. Fish culture in fisheries management. American Fisheries Society, Fish Culture Section and Fisheries Management Section, Bethesda, Maryland.

Raibley, P. T., K. S. Irons, T. M. O'Hara, and K. D. Blodgett. 1997. Winter Habitats Used by Largemouth Bass in the Illinois River, a Large River-Floodplain Ecosystem. North American Journal of Fisheries Management 17:401-412.

Reynolds, J. B. 1996. Electrofishing. Pages 221-253 in B. R. Murphy amd D. W. Willis, editors. Fisheries techniques, $2^{\text {nd }}$ editition. American Fisheries Society, Bethesda, Maryland.

Ryan, M. J., M. A. Webb, and L. T. Fries. 1996. Contribution of Largemouth Bass Reared in Nursery Ponds to Year Classes in Two Texas Reservoirs. Proc. Annu. Conf. Southeast. Assoc. Fish and Wildlife Agencies 50:131-138. 
Sammons, S. M., and P. W. Bettoli. 1999. Spatial and Temporal Variation in Electrofishing Catch Rates of Three Species of Black Bass (Micropterus spp.) from Normandy Reservoir, Tennessee. North American Journal of Fisheries Management. 19:454-461.

Satterfield, J. R., and S. A. Flickinger. 1986. Use of Yearling Largemouth Bass for Initial Stocking of Small Impoundments. Pages 375-380 in R. H. Stroud, editor. Fish culture in fisheries management. American Fisheries Society, Fish Culture Section and Fisheries Management Section, Bethesda, Maryland

Savitz, J., F. A. Fish, and R. Weszely. 1983. Effects of Forage on Home-Range Size of Largemouth Bass. North American Journal of Fisheries Management 112:772-776.

Schell, S. A., D. J. Bright, J. A. Marshall, and M. A. Greenlee. 1996. Ohio River Recreational Use Survey 1992-1993. Ohio Department of Natural Resources. Federal Aid in Sport Fish Restoration Project F-69-P.

Sheehan, R. J., and J. L. Rasmussen. 1999. Large Rivers. Pages 521-559 in C.C. Kohler, and W.A. Hubert editors. Inland Fisheries Management in North America, $2^{\text {nd }}$ Edition. American Fisheries Society, Bethesda, Maryland.

Smith B.W., and W. C. Reeves. 1986. Stocking warmwater species to restore or enhance fisheries. Pages 17-29 in Stroud (1986).

Snow, H. E. 1978. Responses of northern pike exploitation in Murphy Flowage, Wisconson. Spec. Pulb. 11:320-327. American Fisheries Society, Methesda, Maryland.

Snow, J. R. 1968. Production of six to eight inch largemouth bass for special purposes. The Progressive Fish-Culturist, 30:144-152. 
Stauffer, J. R., J. M. Boltz, and L. R. White. 1995. The Fishes of West Virginia. Academy of Natural Sciences of Philadelphia.

Storck, T. W. 1986. Importance of Gizzard Shad in the Diet of Largemouth Bass in Lake Shelbyville, Illinois. Transactions of the American Fisheries Society 115:21-27.

Terre, D. R., S. J. Magnelia, and M. J. Ryan. 1993. Year Class Contribution of Genetically-marked Florida x Northern Largemouth Bass Stocked in Three Texas Reservoirs. Proc. Annu. Conf. Southeast. Assoc. Fish and Wildl. Agencies 47:622-632.

Tranquilli, J. A., and W. F. Childers. 1982. Growth and Survival of Largemouth Bass Tagged with Floy Anchor Tags. North American Journal of Fisheries Management. 2:184-187.

Trautman, Milton B. The Fishes of Ohio. 1981. Ohio State University Press.

Twedt, D. J., W. C. Guest,, and B. W. Farquhar. 1992. Selective Dipnetting of Largemouth Bass during Electrofishing. North American Journal of Fisheries Management 12:609-611.

Wilbur, R. L., and R. M. Duchrow. 1973. Differential retention of five Floy tags on largemouth bass (Micropterus salmoides) in hatchery ponds. Proceedings of the Annual Conference Southeastern Association of Game and Fish Commissioners 26(1972):407-413.

Zweiacker, P. L., and B. E. Brown. 1971. Production of a minimal largemouth bass population in a 3,000 acre turbid Oklahoma reservoir. American Fisheries Society Special Publication 8:481-493 
Table 1. - Lengths and weights of adult and intermediate size hatchery reared bass stocked into Ohio River embayments during October, 1998.

\begin{tabular}{|c|c|c|c|c|}
\hline & \multicolumn{2}{|c|}{ ADULT } & \multicolumn{2}{|c|}{ INTERMEDIATE } \\
\hline & French Creek & Little Mill Creek & French Creek & Little Mill Creek \\
\hline Mean total length (mm) & 274 & 274 & 179 & 179 \\
\hline Range & $190-348$ & $160-366$ & $97-264$ & $85-262$ \\
\hline $95 \% \mathrm{CI}$ & $234-312$ & $224-323$ & $146-209$ & $145-212$ \\
\hline Mean weight (g) & 264 & 264 & 77 & 76 \\
\hline Range & $80-662$ & $47-619$ & $15-275$ & $25-193$ \\
\hline $95 \% \mathrm{CI}$ & $132-396$ & $118-411$ & $27-128$ & $26-125$ \\
\hline
\end{tabular}


Table 2. - Numbers and densities of adult and intermediate size largemouth bass stocked into each study embayment during October 1998.

\begin{tabular}{|c|c|c|}
\hline & French Creek & Little Mill Creek \\
\hline Embayment size (ha) & 48 & 9 \\
\hline $\begin{array}{l}\text { Number of intermediate } \\
\text { bass stocked }\end{array}$ & 2,641 & 647 \\
\hline $\begin{array}{l}\text { Number of adult } \\
\text { bass stocked }\end{array}$ & 1,009 & 240 \\
\hline $\begin{array}{l}\text { Intermediate density } \\
\text { (fish/ha) }\end{array}$ & 55 & 72 \\
\hline $\begin{array}{l}\text { Adjusted intermediate } \\
\text { density }^{\mathrm{a}} \text { (fish/ha) }\end{array}$ & 41 & 53 \\
\hline Adult density (fish/ha) & 21 & 27 \\
\hline $\begin{array}{l}\text { Adjusted intermediate } \\
\text { density }^{\text {a }} \text { (fish/ha) }\end{array}$ & 10 & 13 \\
\hline
\end{tabular}

${ }^{\mathrm{a}}$ Adjusted to compensate for estimated mortality due to hauling and tagging 
Table 3. Chi Square test comparing the return rate of adult versus intermediate sized hatcheryreared largemouth bass in electrofishing surveys. A significant difference $(\mathrm{p}<0.0005)$ indicated that adult largemouth bass returned to electrofishing surveys at a higher rate than the intermediate size class based upon stock rates. This suggests that the adult size class used for stocking may have exhibited higher post-stocking survival.

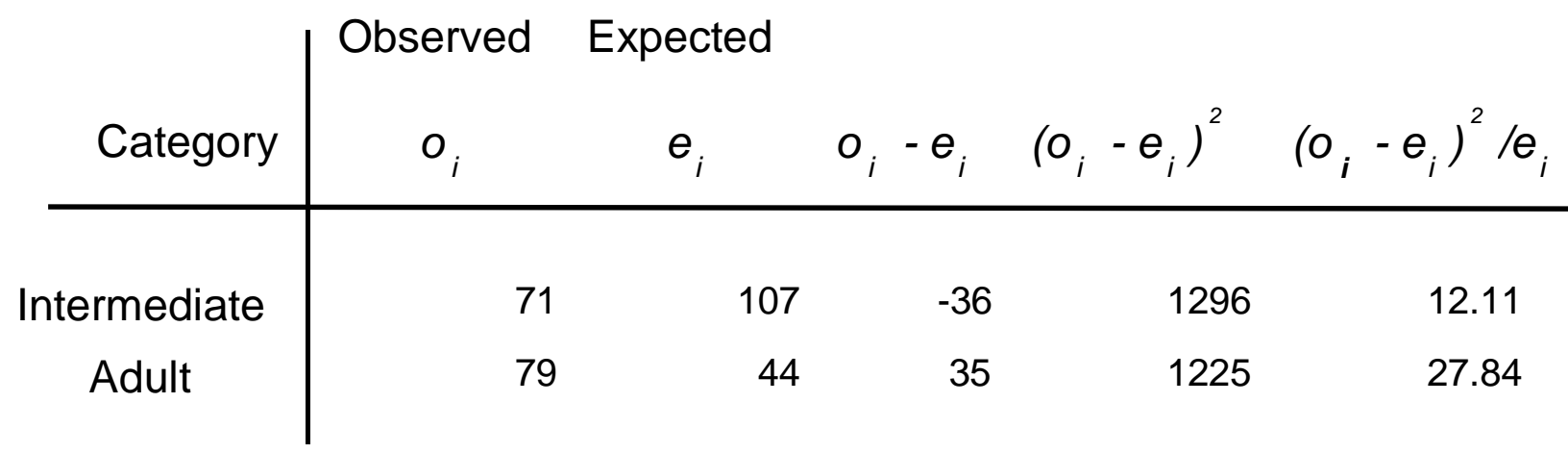

$$
\begin{array}{r}
X^{2}=39.95 \\
p<0.0005
\end{array}
$$


Table 4. - Relative survival of largemouth bass stocked as adult versus those stocked as intermediates based upon electrofishing surveys and angler call-in returns.

\begin{tabular}{|c|c|c|c|c|c|}
\hline $\begin{array}{l}\text { Means of data } \\
\text { collection }\end{array}$ & $\begin{array}{l}\text { Size-class of } \\
\text { stocked fish }\end{array}$ & $\begin{array}{l}\text { Percent of total } \\
\text { originally stocked }\end{array}$ & $\begin{array}{l}\text { Number of } \\
\text { Fish returned }\end{array}$ & $\begin{array}{l}\text { Percent of } \\
\text { total returned }\end{array}$ & Relative survival \\
\hline
\end{tabular}

$\begin{array}{llcccc}\text { Electrofishing } & \text { Intermediate } & 72.5 & 71 & 47.3 & 1.0 \\ \text { surveys } & \text { Adult } & 27.5 & 79 & 52.7 & 2.9\end{array}$

\begin{tabular}{|c|c|c|c|c|c|}
\hline & Intermediate & 72.5 & 20 & 55.6 & 1.0 \\
\hline reports & Adult & 27.5 & 16 & 44.4 & 2.1 \\
\hline
\end{tabular}


Table 5. - Catch per unit effort of stocked and wild largemouth bass capture during black bass tournaments held in the Racine and Willow Island Pool.

Number of tournaments attended

Number of tagged LMB

$<304^{\mathrm{a}} \mathrm{mm}$ reported

Number of tagged LMB

$>304^{\mathrm{a}} \mathrm{mm}$ total length

CPUE $^{\mathrm{b}}$ of wild LMB

$>304^{\mathrm{a}} \mathrm{mm}$ total length

CPUE $^{\mathrm{b}}$ of stocked LMB

$>304^{\mathrm{a}} \mathrm{mm}$ total length

$\mathrm{CPUE}^{\mathrm{b}}$ of stocked LMB

$<304^{\mathrm{a}} \mathrm{mm}$ total length
1999

16

2000

10

15

0

0

7

0.0400

0.1111

0.0000

0.0011

0.0012

0.0000

a $304 \mathrm{~mm}$ total length = minimum tournament size.

${ }^{\mathrm{b}}$ Number of fish captured per hour of tournament angling effort. 
Table 6. Chi Square test comparing the return rate of adult versus intermediate size hatchery reared largemouth bass based upon angler call-in reports. A significant difference $(\mathrm{p}<0.05)$ indicated that adult largemouth bass returned to anglers' creel at a higher rate than the intermediate size class based upon stock rates. This suggests that the adult size class used for stocking may have exhibited higher post-stocking survival.

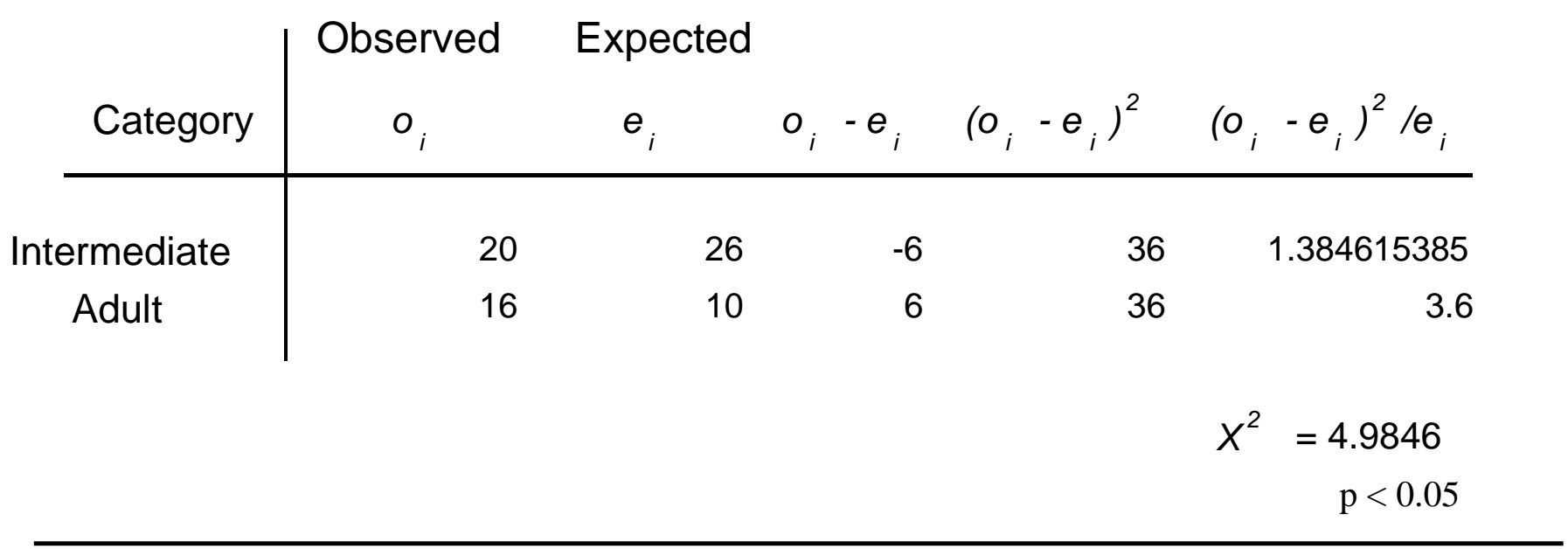




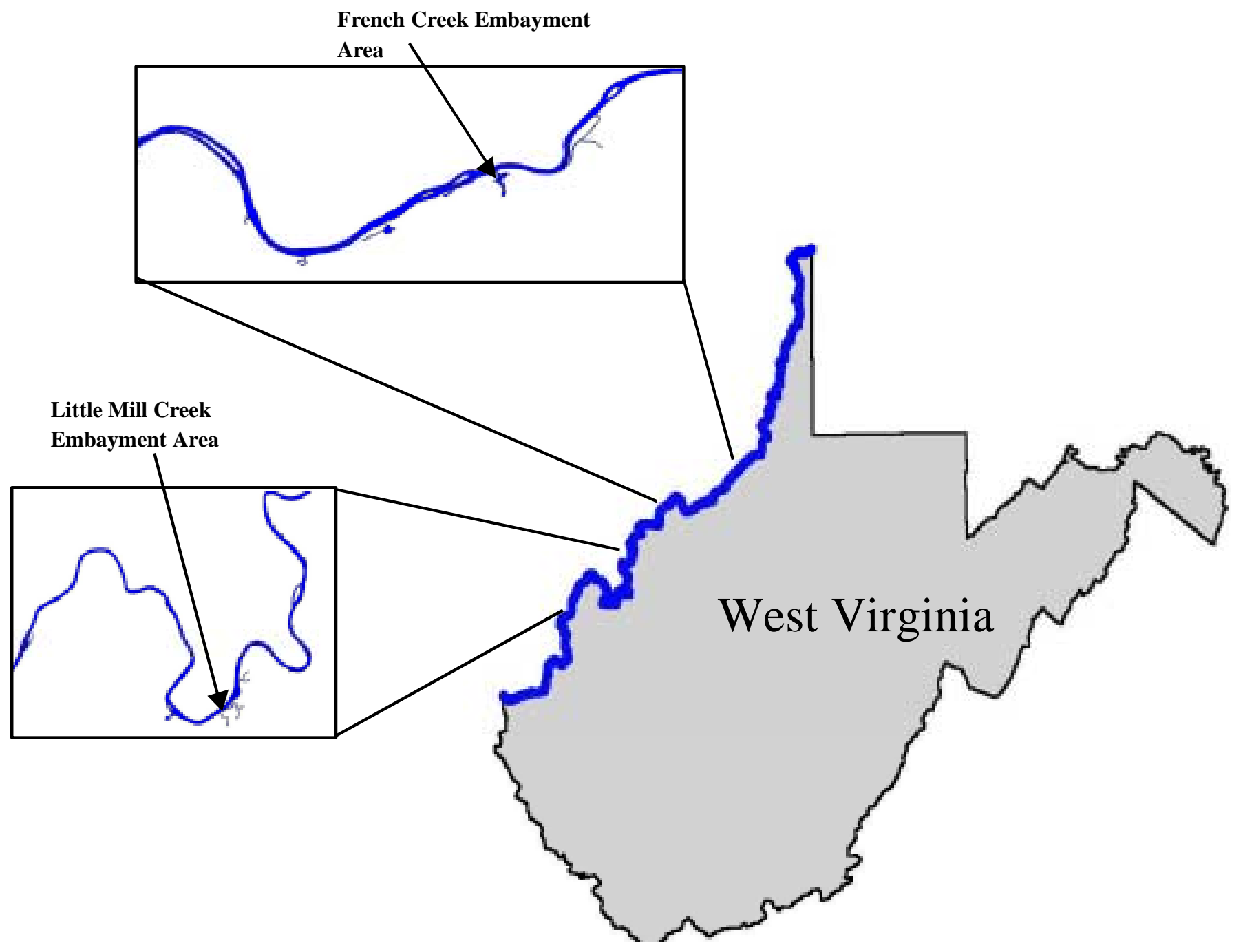

Figure 1. Map of Ohio River showing embayments areas used for stocking 


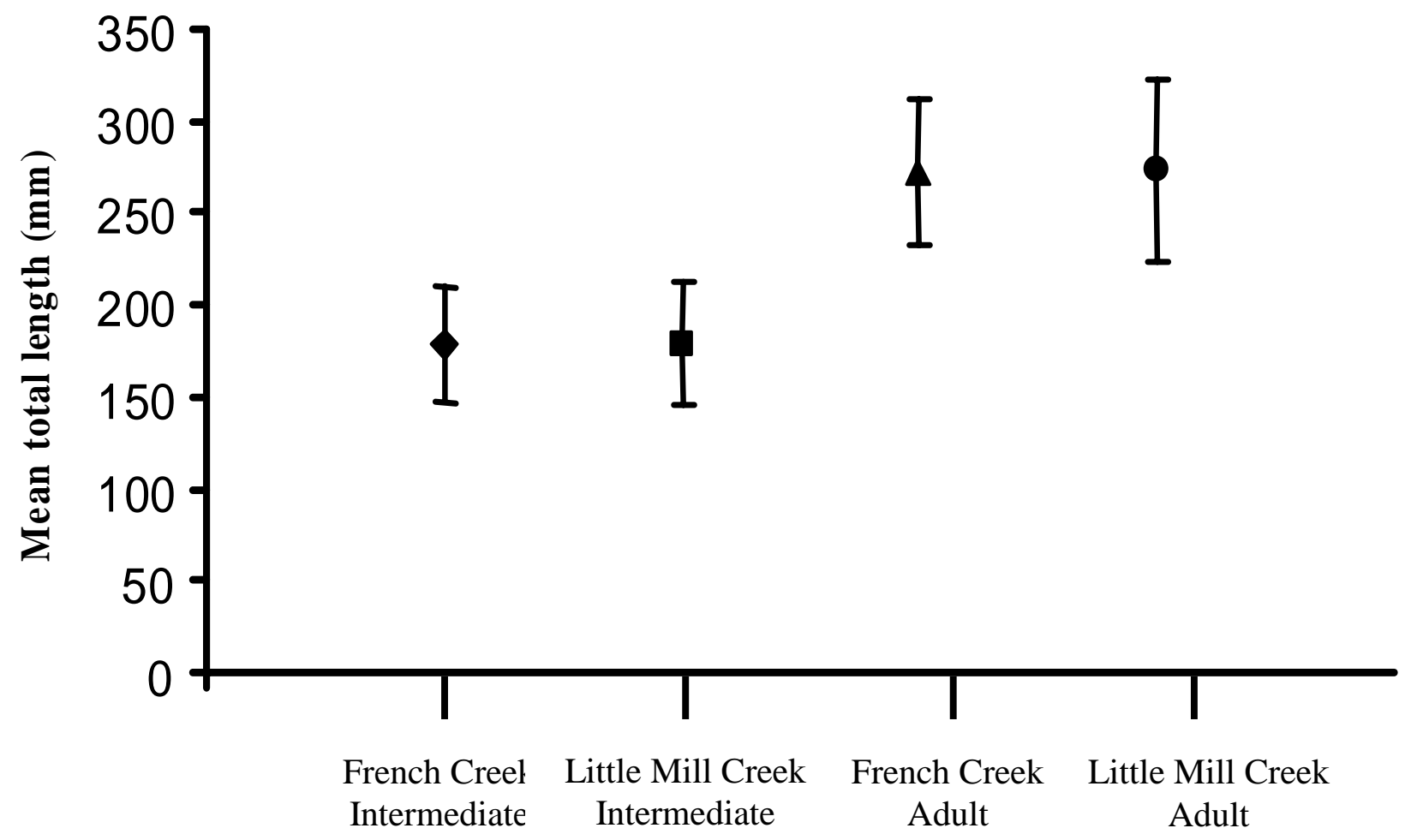

Figure 2. Mean length comparisons for the two largemouth bass size classes stocked. 


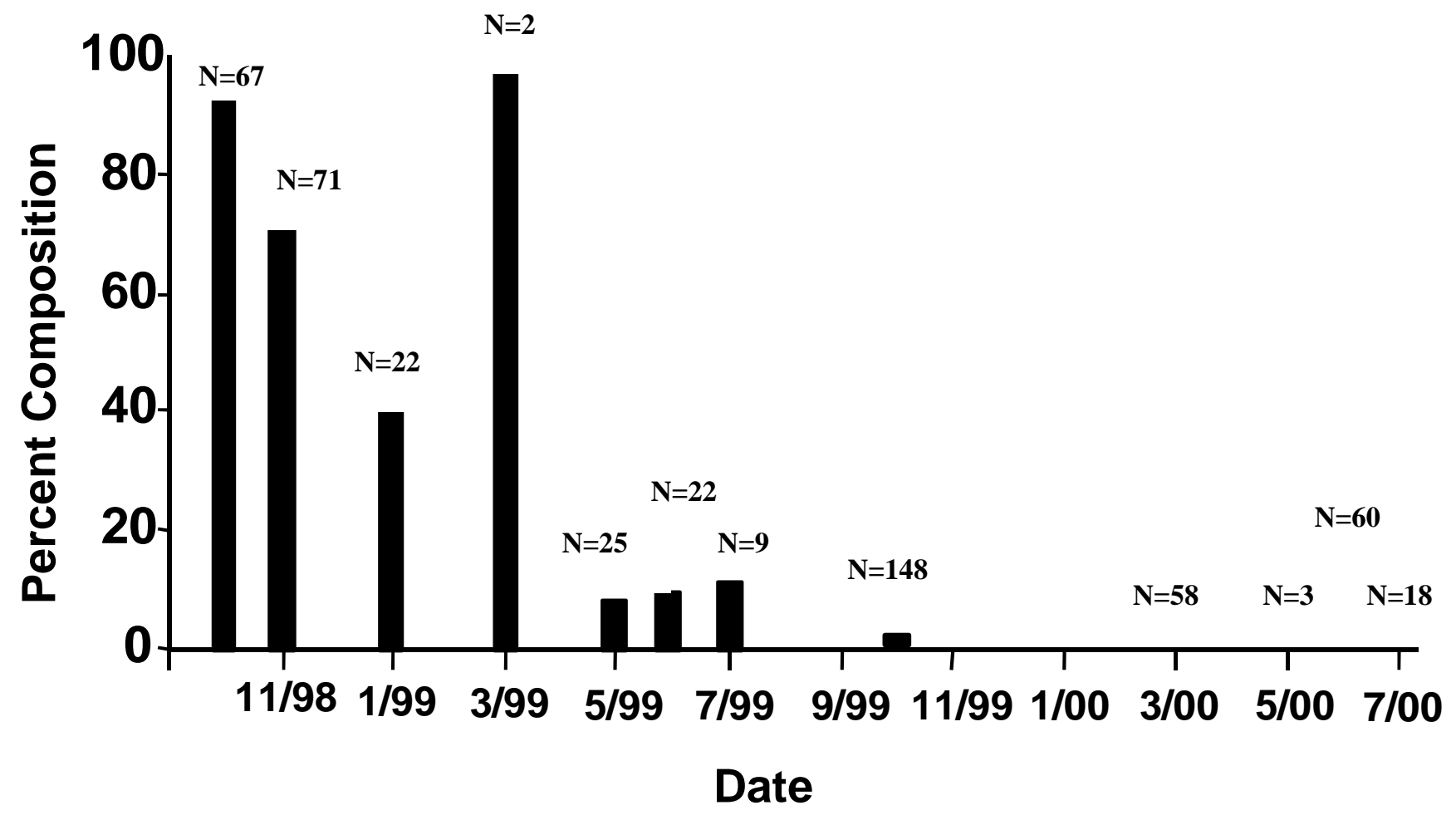

Figure 3. Percent of total monthly electrofishing catch comprised of stocked bass in French, and Little Mill Creek, West Virginia between 20 October 1998 and 7 July 2000. 


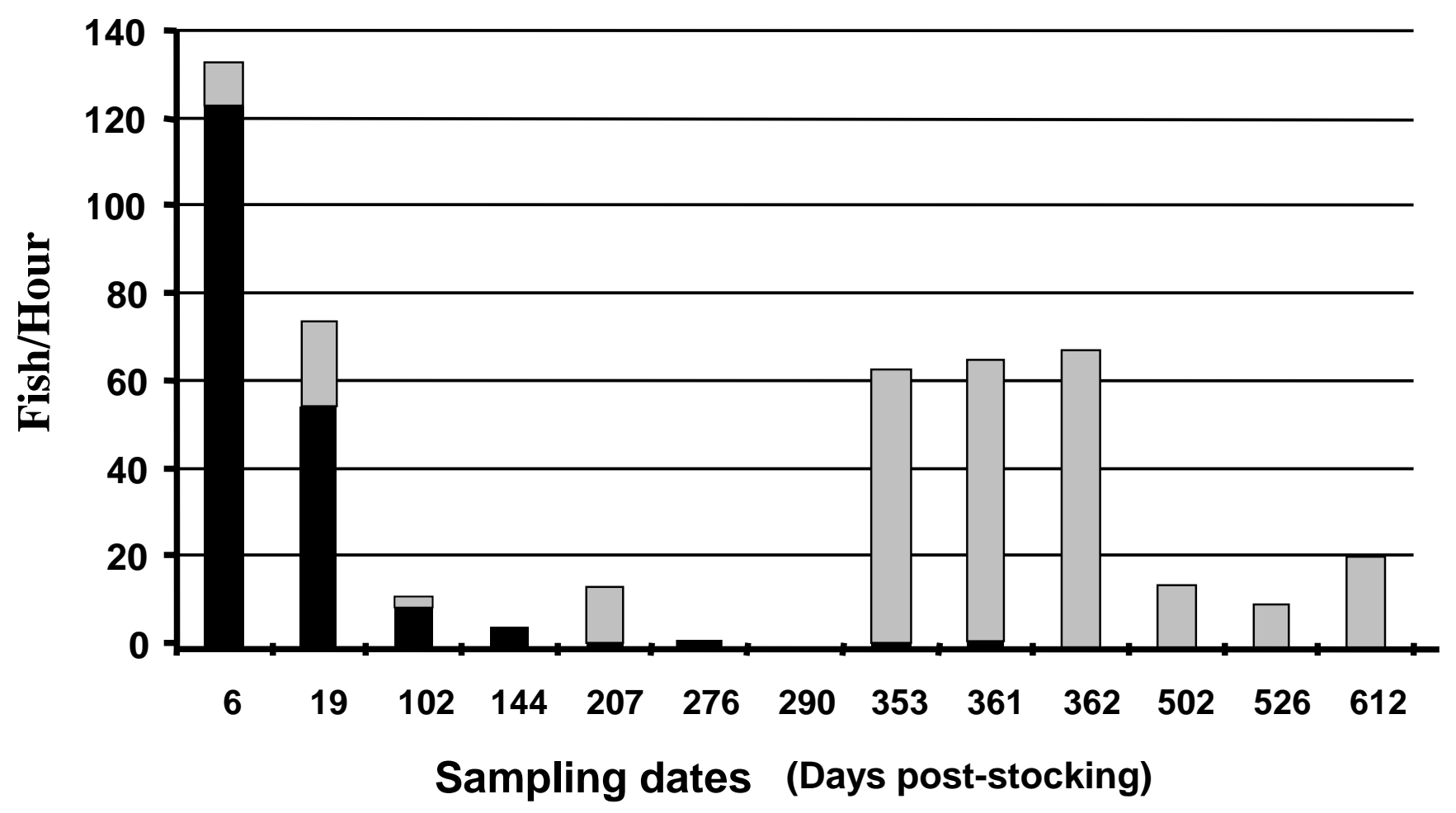

Figure 4. Catch per unit effort of wild versus stocked largemouth bass during French Creek Electrofishing surveys.

Wild largemouth bass $=\square \quad$ Stocked largemouth bass $=$ 
A.

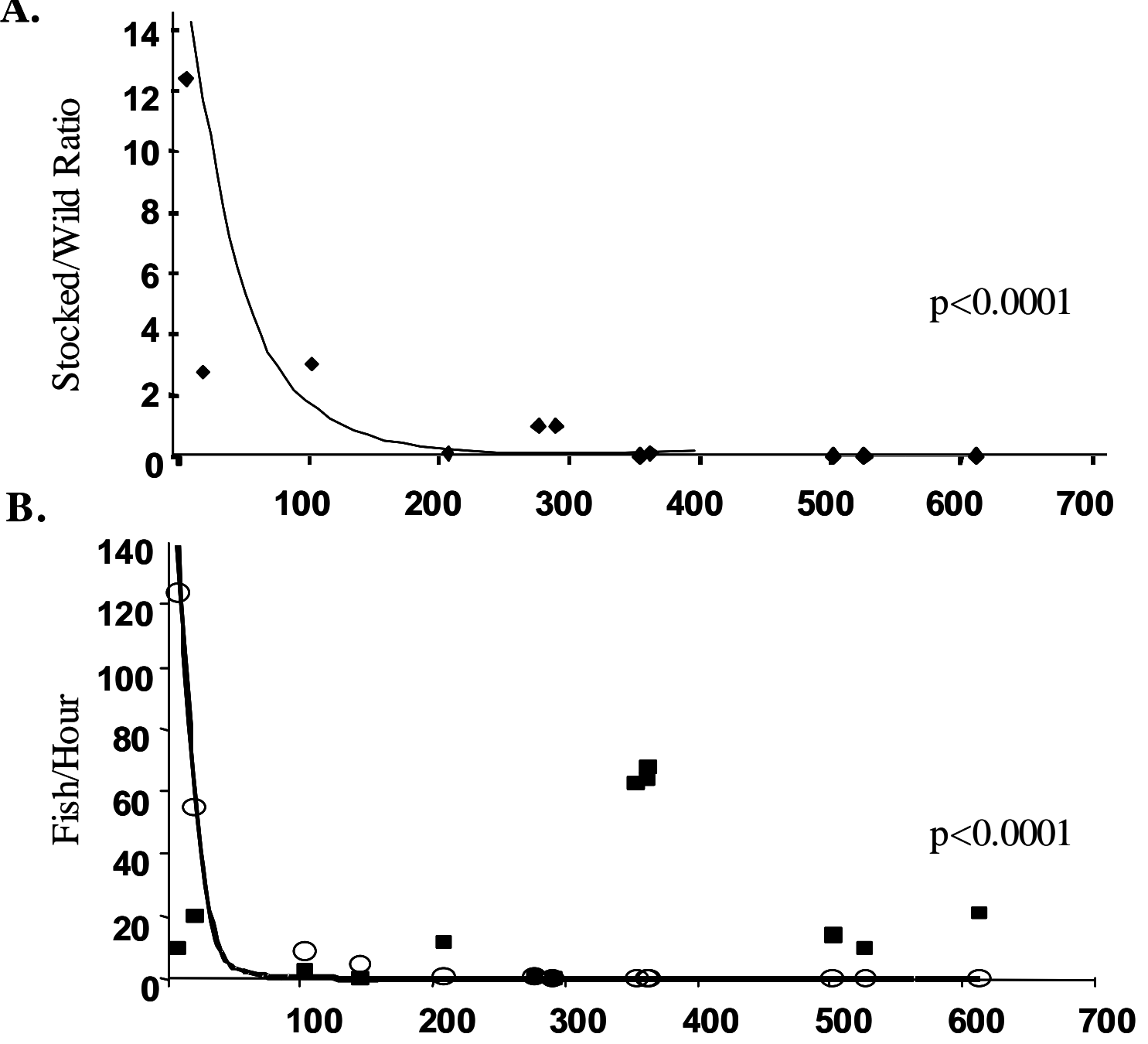

Days Post Stocking

Figure 5. The relationship between days post-stocking and two measures of catch for wild and hatchery largemouth bass: the ratio of stocked to wild fish (panel A) and number of fish captured per electrofishing hour (panel B). Wild largemouth bass are depicted by closed squares and hatchery-reared largemouth bass by open circles. Both regression relationships are a significant negative exponential function. 


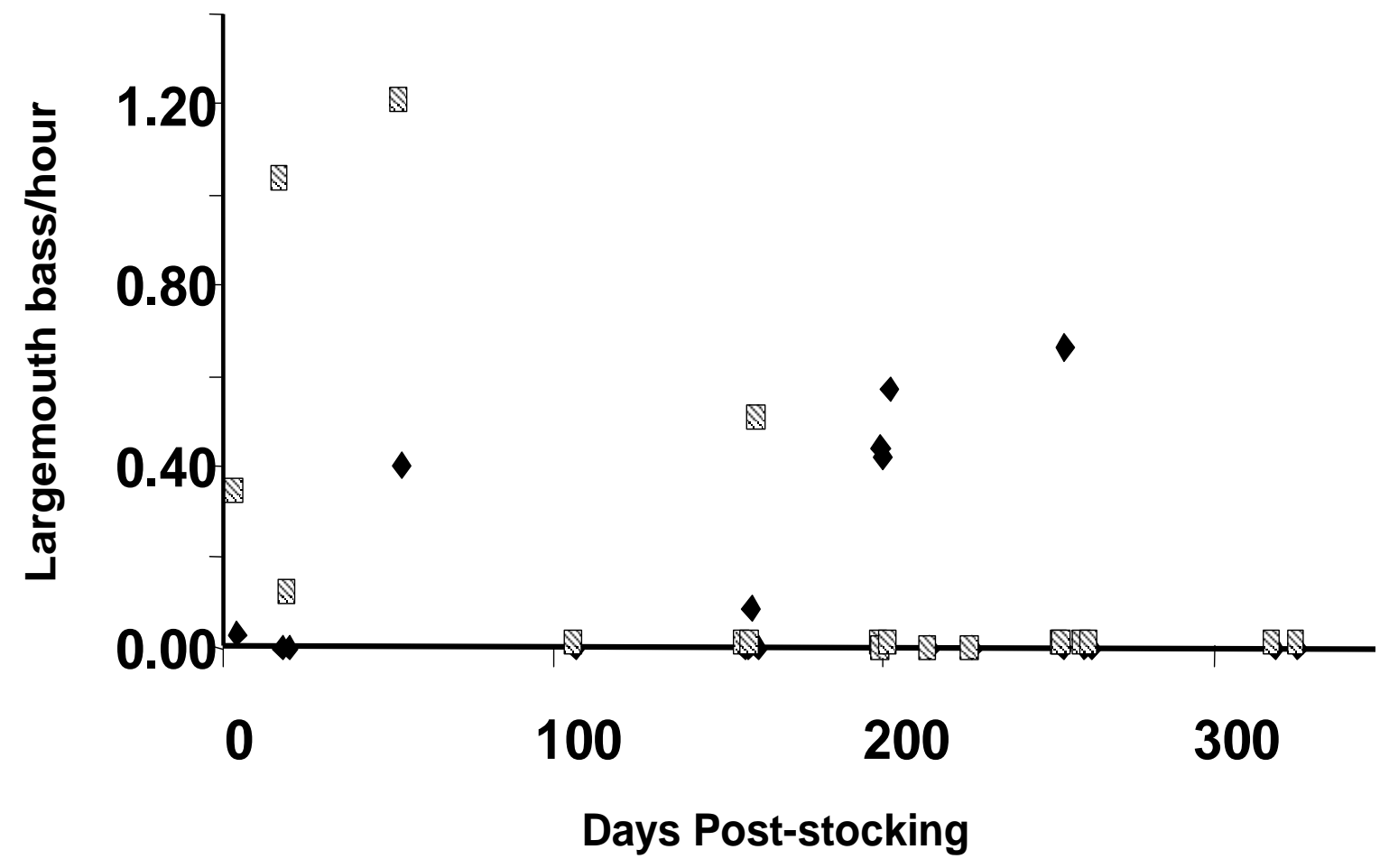

Figure 6. Comparison of stocked (diagonal filled squares) and wild bass (closed diamonds) catch rates from creel surveys conducted in Little Mill and French Creek, WestVirginia between October 1998 and June 2000. 


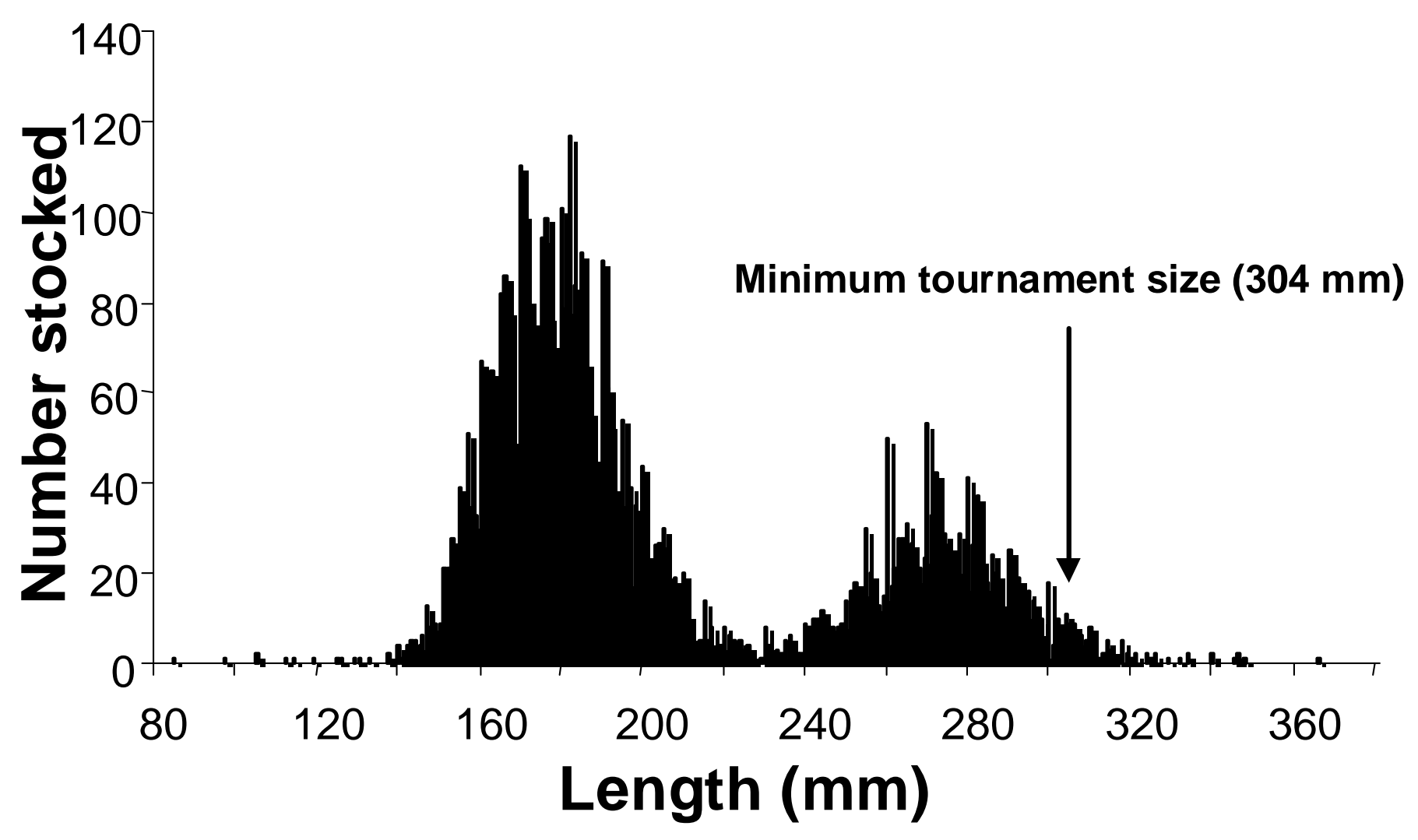

Figure 7. Length frequency histogram of hatchery reared largemouth bass at the time time of stocking into French Creek and Little Mill Creek, West Virginia on 20 October 1998. 


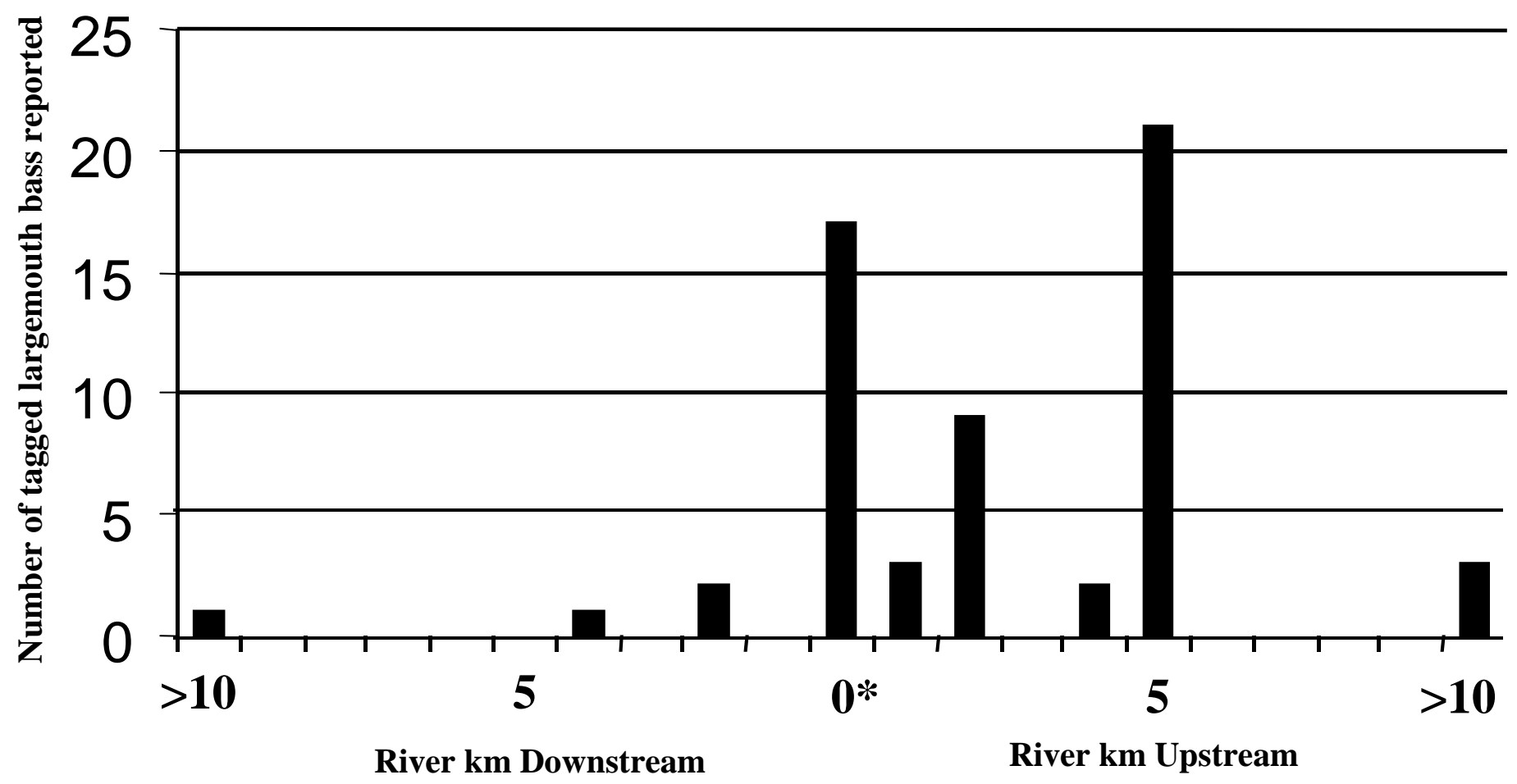

Figure 8. Distances from site of stocking of captured fish as reported by anglers.

* A value of zero denotes that the tagged bass was captured in French or Little Mill Creek. 